$1-1-2014$

\title{
To the Victor Goes the Toil - Remedies for Regulated Parties in Separation-of-Powers Litigation
}

\author{
Kent H. Barnett \\ University of Georgia School of Law, khbarn@uga.edu
}

Prepress SSRN

\section{Repository Citation}

Kent H. Barnett, To the Victor Goes the Toil -- Remedies for Regulated Parties in Separation-of-Powers Litigation, 92 N.C. L. Rev. 481 (2014),

Available at: https://digitalcommons.law.uga.edu/fac_artchop/943

This Article is brought to you for free and open access by the Faculty Scholarship at Digital Commons @ University of Georgia School of Law. It has been accepted for inclusion in Scholarly Works by an authorized administrator of Digital Commons @ University of Georgia School of Law. Please share how you have benefited from this access For more information, please contact tstriepe@uga.edu. 


\title{
TO THE VICTOR GOES THE TOIL-REMEDIES FOR REGULATED PARTIES IN SEPARATION- OF-POWERS LITIGATION*
}

\begin{abstract}
KENT BARNETT ${ }^{* *}$
The U.S. Constitution imposes three key limits on the design of federal agencies. It constrains how agency officers are appointed, the extent of their independence from the President, and the range of issues that they can decide. Scholars have trumpeted the importance of these safeguards with soaring rhetoric. And the Supreme Court has permitted regulated parties to vindicate these safeguards through implied private rights of action under the Constitution. Regulated parties, for their part, have been successfully challenging agency structure with increased frequency-as the recent ongoing separation-of-powers actions against the National Labor Relations Board ("NLRB") and Consumer Financial Protection Bureau ("CFPB") indicate. At the same time, regulated parties, courts, and scholars have largely ignored the practical question of "structural remedies"-i.e., how to remedy the violation of structural safeguards for prevailing regulated parties. This inattention may arise because courts often provide what seems at first blush to be an appropriate remedy: severing the structural defect from an agency's "organic" act. In fact, however, structural remedies often fail to satisfy core remedial values relevant to regulated parties-namely, compensating past harm, preventing future harm from the past defect, incentivizing regulated parties to seek redress, and deterring structural violations-and may even leave regulated parties in a worse place than they occupied before asserting the challenge. These ineffectual remedies thereby undermine the very safeguards that judicial decisions purport to vindicate and render any "private right" potentially illusory. Courts, in response, can improve the status quo. They could select (or Congress could provide) better remedies, and this Article considers how they could do so. But if structural remedies cannot be sufficiently
\end{abstract}

* (C) 2014 Kent Barnett.

** Assistant Professor, University of Georgia School of Law. I appreciate helpful comments from Bill Araiza, Dan Coenen, Ron Krotoszynski, Jeff Lubbers, Sharon Rush, Mark Seidenfeld, David Shipley, Chris Walker, Kathryn Watts, and participants of the 2012 Southeastern Law Schools Junior/Senior Faculty Workshop at Tulane University Law School. 
improved, courts should either become more candid about the underlying safeguards' limitations or reconsider altogether the nature of the safeguards and regulated parties' relationship to them.

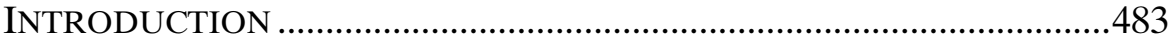

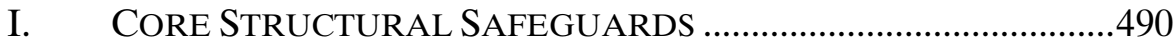

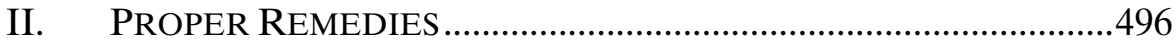

A. The Importance of Remedies ................................................496

1. Rights and Remedies' Interdependence.......................497

2. Rights and Remedies' Independence............................499

B. Key Remedial Values............................................................500

1. Compensation for Past Harm and Prospective

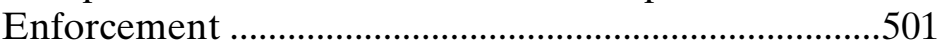

2. Incentives to Pursue Redress ........................................509

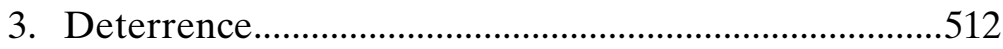

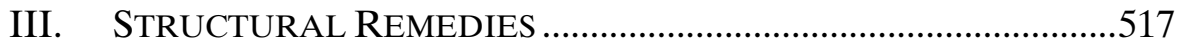

A. Severing the Structural Violation............................................518

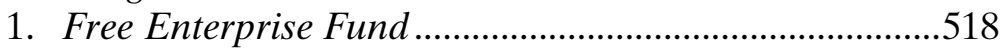

2. Intercollegiate Broadcasting System.............................521

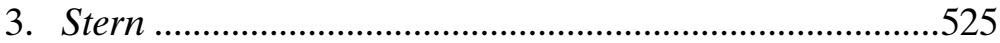

B. Requiring Legislative or Executive Action .........................527

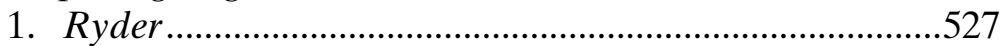

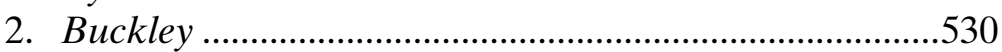

3. Northern Pipeline .........................................................534

IV. RESPONDING TO STRUCTURAL REMEDIATION'S

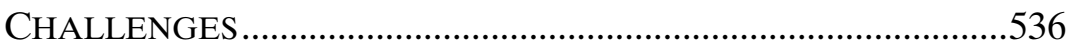

A. Improving Remedies .....................................................536

1. Briefing Remedial Options ..........................................536

2. Liberalized Equitable Remedies ...................................538

3. Legislative Participation .............................................539

B. Judicial Candor Concerning Safeguards' Limitations ........541

C. Limiting Challenges from Regulated Parties .......................544

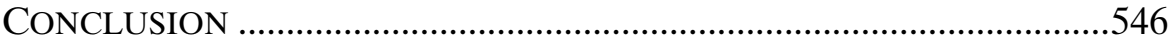




\section{INTRODUCTION}

"Next to a battle lost, the greatest misery is a battle gained." -Arthur Wellesley, Duke of Wellington ${ }^{1}$

For nearly two decades, the United States Supreme Court has welcomed regulated parties' separation-of-powers challenges to the federal administrative state. These constitutional challenges include efforts to limit agencies' power based upon the Appointments Clause, the President's implied supervisory powers under Article II, and the judiciary's powers under Article III. ${ }^{2}$ The Court has indicated that prevailing litigants are entitled to a meaningful remedy ${ }^{3}$ and has recognized private rights of action under the Constitution to assert these structural challenges. ${ }^{4}$ Parties that are regulated by federal administrative agencies have noted the Court's apparent enthusiasm and have begun regularly asserting these and other structural challenges, including recent ones based on the President's recess appointments of certain members to the NLRB and the director of the CFPB. ${ }^{5}$ But prevailing regulated parties often obtain not only an unsatisfactory judicial remedy, but one that may place them in an even worse position than the one they occupied before bringing suit. The remedies, too, may be ill-defined and may fail to resolve what effect a separation-of-powers violation has on other agency actions and other regulated parties. These remedial deficiencies result from the failure to consider familiar remedial values when crafting remedies for structural or systemic violations to the administrative

1. Frances SPALding, John PiPER, MYFAnWy PIPER: LiVES IN ART 433 (2009).

2. Other structural challenges exist, but they are much less common. See generally INS v. Chadha, 462 U.S. 919 (1983) (concerning the "legislative veto"); A.L.A. Schechter Poultry Corp. v. United States, 295 U.S. 495 (1935) (concerning the nondelegation doctrine). The remedies for these challenges are less troubling than the remedies for successful structural challenges discussed in this Article because the prevailing party obtains meaningful substantive relief. See, e.g., Chadha, 462 U.S. at 928 (invalidating congressional action that would have led to the immigrant's deportation); Schechter, 295 U.S. at 551 (reversing the defendants' conviction).

3. See Ryder v. United States, 515 U.S. 177, 188 (1995).

4. See Free Enter. Fund v. Pub. Co. Accounting Oversight Bd., 130 S. Ct. 3138, 3151 n.2 (2010).

5. See generally New Process Steel, L.P. v. NLRB, 560 U.S. 674 (2010) (holding that the NLRB lacked a quorum under the governing statute to act); Noel Canning v. NLRB, 705 F.3d 490 (D.C. Cir. 2013) (holding that the recess appointments of NLRB members were unconstitutional), cert. granted 133 S. Ct. 2861 (U.S. June 24, 2013) (No. 12-1281); Richards v. NLRB, 702 F.3d 1010 (7th Cir. 2012) (dismissing a challenge to recess appointments based on lack of standing); First Amended Complaint for Declaratory and Injunctive Relief IIII 240-45, State Nat'l Bank of Big Spring v. Geithner, No. 1:12-cv-01032 (D.D.C. Sept. 20, 2012), 2012 WL 4229466 (asserting several structural challenges to the CFPB). 
state. This failure, in turn, limits the efficacy of the very structural safeguards that courts purport to vindicate.

For a concrete sense of the problem, consider the Supreme Court's recent decision in Free Enterprise Fund v. PCAOB ${ }^{6}$ There, the Public Company Accounting Oversight Board ("PCAOB") had begun investigating the auditing practices of the plaintiff, an accounting firm. ${ }^{7}$ The Sarbanes-Oxley Act ("SOX") established the board as an independent entity within the Securities Exchange Commission ("SEC"), itself an independent agency, to regulate accounting and auditing firms. ${ }^{8}$ The SEC appointed the board's members and could remove them for certain causes. ${ }^{9}$ The plaintiff argued that the board's independence improperly impeded the President's supervisory powers under Article II. ${ }^{10}$ The Court agreed, holding that the board members enjoyed too much protection from at-will removal. ${ }^{11}$ However, the Court did not prevent the board from taking any actions under SOX, as the plaintiffs had requested. ${ }^{12}$ Instead, it simply severed the board members' statutory protection from removal from office by the SEC, rendering them removable at will and thus sufficiently subject to presidential oversight to cure the structural defect. ${ }^{13}$ The Court remanded the matter to the board for further proceedings, ${ }^{14}$ declaring SOX "fully operative." 15

This remedy might seem proportionate to the violation. By permitting the SEC to remove the board members at will, the Court addressed the structural harm in the statutory scheme. Invalidating all of the board's powers would seem too severe a sanction when the Court could easily sever the offending provision. The remedy also

6. 130 S. Ct. 3138 (2010)

7. Id. at 3149 .

8. Id. at 3147 .

9. Id. at 3147-48. These causes that served as the basis for removal proceedings were

that the $[\mathrm{PCAOB}]$ member "(A) has willfully violated any provision of th[e SOX] Act, the rules of the Board, of the securities laws; (B) has willfully abused the authority of that members; or (C) without reasonable justification or excuse, has failed to enforce compliance with any such provision or rule, or any professional standard by any registered public accounting firm or associated person thereof."

Id. at 3148 (quoting 15 U.S.C. $§ 7217(\mathrm{~d})(3)(2006)$.

10. Id. at 3149 .

11. See id. at 3151-61.

12. See id. at 3161.

13. See id.

14. Id. at 3164 .

15. Id. at 3161 (internal quotations omitted). 
appeared to comport with settled norms of judicial restraint and attentiveness to Congress's likely fallback position. ${ }^{16}$

But the remedy from the prevailing litigant's vantage point looks different. Despite the firm's successful structural challenge, the Court provided an inconsequential remedy. It did not prevent the board from functioning, invalidate any past actions of the board, ${ }^{17}$ enjoin the board from investigating the regulated firm, require a wholly new administrative investigation, or limit the board's substantive powers. ${ }^{18}$ The accounting firm recovered no damages or attorneys' fees, despite the availability of such compensation in other constitutional litigation. ${ }^{19}$ Instead, the investigation simply continued with proceedings, at least in the firm's view, before potentially hostile board members who were now stripped of independence from the SEC and the President. Whether the board members would actually retaliate against the firm hardly matters to a regulated party; the mere risk of subtle retaliation is likely enough to counsel caution. Ultimately, the prevailing litigant incurred significant costs only to end up where it began, except this time before a potentially resentful board. The accounting firm could be forgiven for wondering why it brought a structural challenge at all. And future litigants-especially those that repeatedly interact with an agency-might think it wise to ignore other structural defects.

Consider, too, the remedy from Congress's perspective. Congress created the PCAOB and impinged upon the President's supervisory power. But Congress paid little, if any, price for its constitutional violation. The board lost no substantive powers, and the Court did not task Congress with rethinking the board's structure. Despite losing the power to structure the administrative state in a particular way, Congress paid no serious price for establishing an unconstitutional agency. Indeed, after Free Enterprise Fund, substantive decisions remain shielded from the President's control. In

16. See id.; Brianne J. Gorod, The Collateral Consequences of Ex Post Judicial Review, 88 WASH. L. REV. 903, 952-53 (2013).

17. In Free Enterprise Fund, the agency had not yet issued a final order. See Free Enter. Fund, 130 S. Ct. at 3150-51 (permitting review of the constitutional issue despite no final agency action).

18. See infra Part III for a discussion of remedies in other separation-of-powers litigation.

19. See, e.g., 42 U.S.C. $\$ \S 1983,1988$ (2006) (permitting damages and attorneys' fees for federal law violations by those acting under color of state law); Bivens v. Six Unknown Named Agents, 403 U.S. 388, 390-97 (1971) (providing damages against federal officers for Fourth Amendment violations). 
light of the Court's remedy, future Congresses may wonder why they should bother considering structural matters.

Buckley v. Valeo $^{20}$ illustrates similar points. There, the Court held that all members of the Federal Election Commission ("FEC") were installed in violation of the Appointments Clause. ${ }^{21}$ The prevailing parties requested that the Court shut down the FEC and invalidate all of its powers and prior actions. ${ }^{22}$ The Court, however, while invalidating the FEC's future exercise of "executive" powers, validated the agency's past actions. ${ }^{23}$ The parties, despite prevailing, were thus bound by an unconstitutionally constituted body's actions. Moreover, the Court stayed its judgment for thirty days, permitting the FEC to wield its original powers during that transitive period in which Congress could consider how to restructure the Commission. ${ }^{24}$ Put simply, the Court permitted what was probably the most structurally defective agency ever created to continue to act and validated its past actions. ${ }^{25}$

Free Enterprise Fund and Buckley are not aberrational. Other decisions' remedies for systemic violations reveal similar deficiencies. ${ }^{26}$ These problems, too, are almost sure to proliferate because of the increased frequency of structural challenges by regulated parties, the Court's increasingly formal separation-ofpowers doctrines, and Congress's failure to comply with structural safeguards when fashioning administrative structures in the recent past. ${ }^{27}$ Indeed, aside from the challenges discussed in detail later in this Article, regulated parties have recently (and sometimes successfully) asserted separation-of-powers challenges against the CFPB and the NLRB to prevent the agencies from acting, but they have done so without confronting the possibility of receiving an inadequate remedy. ${ }^{28}$ When successful, these parties have not

20. 424 U.S. 1 (1976) (per curiam).

21. See id. at 140.

22. See id. at 140 .

23. See id. at $137-42$.

24. See id. at 143.

25. See infra note 291 .

26. See infra Part III.

27. See infra Part I.

28. See supra note 5 and accompanying text; First Amended Complaint for Declaratory and Injunctive Relief III 240-45, State Nat'l Bank of Big Spring v. Geithner, No. 1:12-cv-01032 (D.D.C. Sept. 20, 2012), 2012 WL 4229466; Brief and Required Appendix of Petitioner at 56, Richards v. NLRB, 702 F.3d 1010 (7th Cir. 2012) (Nos. 121973 \& 12-1984) (petitioner's brief requesting that the court remand the matter for action only when the NLRB had a proper quorum); Jim Puzzanghera, Lawsuit Challenges Consumer Protection Bureau, L.A. TIMES (June 22, 2012), http://articles.latimes.com 
obtained clear remedial guidance from the courts, ${ }^{29}$ revealing the timeliness and importance of discussing judicial remedies for structural violations. ${ }^{30}$ There is, too, a deeper problem: the parties rarely brief the issue of remedies in any detail, and the courts rarely even consider remedial alternatives or the normative goals that they have recognized in other settings as critical for fashioning proper remedies. ${ }^{31}$ Given the inextricable connection between rights and remedies ${ }^{32}$ the courts' actions raise broad questions about the meaningfulness and nature of the substantive limits that they have imposed on administrative agencies' structure.

Nor are the courts and parties alone in ignoring remedies. In the 1950s, Professor Charles Alan Wright remarked upon the academy's failure to consider the law of remedies. ${ }^{33}$ In the decades since, scholars have considered judicial remedies for constitutional

/2012/jun/22/business/la-fi-banks-lawsuit-20120623; Kevin Bogardus, Senate Republicans Join Suit Against NLRB Recess Appointments, THE HILL (Sept. 26, 2012), http://thehill.com/business-a-lobbying/258843-senate-republicans-join-suit-against-nlrbrecess-appointments (discussing a recess-appointment challenge brought in the D.C. Circuit)

29. See generally Noel Canning v. NLRB, 705 F.3d 490 (D.C. Cir. 2013) (holding that the recess appointments of NLRB members were unconstitutional but providing no remedial discussion), cert. granted 133 S. Ct. 2861 (U.S. June 24, 2013) (No. 12-1281). Before the Senate confirmed Richard Cordray as director of the CFPB in July 2013, see U.S. Senate Roll Call Votes 113th Congress - 1st Session, Vote Number 174, U.S. SENATE (July 16, 2013), http://www.senate.gov/legislative/LIS/roll_call_lists/roll_call_vote_cfm.cfm ?congress $=113 \&$ session $=1 \&$ vote $=00174$, legal blogs noted the uncertainty that a successful challenge to his recess appointment would have faced, see Alan S. Kaplinsky, The Senate Republicans Officially Weigh In On Cordray's Nomination, CFPB MONITOR BLOG (Feb. 1, 2013), http://www.cfpbmonitor.com/2013/02/01/the-senate-republicans-officially-weighin-on-cordrays-nomination/.

30. Commentators have begun to notice these remedial concerns in separation-ofpowers litigation. See, e.g., Alan S. Kaplinsky, D.C. Circuit May Soon Invalidate President Obama's NLRB Recess Appointments: Implications for CFPB, CFPB MONITOR BLOG (Jan. 10, 2013), http://www.cfpbmonitor.com/2013/01/10/d-c-court-of-appeals-may-sooninvalidate-president-obamas-nlrb-recess-appointments-implications-for-cfpb/ ("Would any or all of the CFPB's actions since Mr. Cordray was appointed be invalid? How do you unscramble the egg? What about future CFPB actions?").

31. For instance, courts consider the values of deterrence and compensation in tort and contract matters, see generally infra Part II.B, and they consider deterrence, incentive to litigate, and other values when fashioning injunctions for violations of certain constitutional rights, see Susan P. Sturm, A Normative Theory of Public Law Remedies, 79 GEO. L.J. 1355, 1358 (1991).

32. See infra Part II.A; $c f$. RANDY BARNETT, CONTRACTS: CASES AND DOCTRINE 59 (5th ed. 2012) ("[T]he precise remedy sought by the parties and awarded by the court will reveal important information about the formation of contract."); Daryl J. Levinson, Rights Essentialism and Remedial Equilibration, 99 COLUM. L. REV. 857, 931 n.317 (1999) (referring to Lon Fuller's contracts casebook that began by discussing remedies).

33. See Charles Alan Wright, The Law of Remedies as a Social Institution, 18 U. DET. L.J. 376, 376 (1955). 
violations, but they have generally concentrated on federalism concerns over injunctions triggered by state and municipal violations of specific constitutional amendments. ${ }^{34}$ Some recent scholarship considers the proper role of injunctive relief for all constitutional violations $^{35}$ and the potential for remedial nuance to mitigate the consequences of invalidating a statute on constitutional grounds generally. ${ }^{36}$ But none of this work has broadly considered the kind of remedies that a regulated party should receive for successfully challenging the structure of the administrative state. ${ }^{37}$ This omission is problematic because, as explored below, structural challenges have characteristics that render an effective remedy for a prevailing regulated party difficult to craft. Likewise, scholars have considered the effect of the Court's recent separation-of-powers jurisprudence on the competing branches of government or constitutional theory. ${ }^{38}$ But they have not considered a more important problem to those under regulatory supervision: whether the Court's structural remedies for regulated parties render the substantive norms practically ineffective.

34. For scholarly discussion of the federalism implications of injunctive relief, see generally Walter E. Dellinger, Of Rights and Remedies: the Constitution as a Sword, 85 HARV. L. REV. 1532 (1972); Owen M. Fiss, Forward: The Forms of Justice, 93 HARV. L. REV. 1 (1979); Paul Gewirtz, Remedies and Resistance, 92 YALE L.J. 585 (1983); Alfred Hill, Constitutional Remedies, 69 COLUM. L. REV. 1109 (1969); Levinson, supra note 32; Henry P. Monaghan, Forward: Constitutional Common Law, 89 HARV. L. REV. 1 (1975); Robert F. Nagel, Separation of Powers and the Scope of Federal Equitable Remedies, 30 StAN. L. REV. 661 (1978); Lawrence G. Sager, Fair Measure: The Legal Status of Underenforced Constitutional Norms, 91 HARV. L. REV. 1212 (1978); Sturm, supra note 31.

35. See John F. Preis, In Defense of Implied Injunctive Relief in Constitutional Cases, 22 WM. \& MARY BILL RTS. J. 1, 5 (2013).

36. See Gorod, supra note 16, at 949-51.

37. The key exception is scholarship that has considered the de facto officer doctrine's proper role in remedying invalid appointments. See infra Part III.B. But see Michael Dorf, Toward a Doctrine of "Constitutionalish" Laws, DORF ON LAW (Jan. 17, 2012, 2:30 AM), http://www.dorfonlaw.org/2012/01/toward-doctrine-of-constitutionalish.html (suggesting that structural remedies should be pragmatic and limited for "constitutionalish" laws, whose fault is "technical").

38. For examples of such scholarship, see generally Kent Barnett, Avoiding Independent Agency Armageddon, 87 NOTRE DAME L. REV. 1349 (2012) [hereinafter Barnett, Independent Agency]; Kent Barnett, The Consumer Financial Protection Bureau's Appointment with Trouble, 60 AM. U. L. REV. 1459 (2011) [hereinafter Barnett, Appointment with Trouble]; Harold J. Krent, Federal Power, Non-Federal Actors: The Ramifications of Free Enterprise Fund, 79 FORDHAM L. REV. 2425 (2011); Ronald J. Krotoszynski, Jr., Cooperative Federalism, the New Formalism, and the Separation of Powers Revisited: Free Enterprise Fund and the Problem of Presidential Oversight of StateGovernment Officers Enforcing Federal Law, 61 DUKE L.J. 1599, 1602-03 (2012); Neomi Rao, A Modest Proposal: Abolishing Agency Independence in Free Enterprise Fund v. PCAOB, 79 FORDHAM L. REV. 2541 (2011). 
Against this backdrop, I turn to three familiar values for assessing the effectiveness of all remedies, including remedies for systemic or structural defect: (1) compensation for and prospective enforcement of the violation, (2) incentives to seek redress, and (3) deterrence of violators. With these values in mind, I examine six leading structural decisions to identify characteristics that often lead structural remedies to achieve key remedial values. ${ }^{39}$ These characteristics include requiring Congress or the President to confront the structural defect and choose how to respond, providing new administrative proceedings for the prevailing party after a court's ruling, and invalidating an agency's actions taken while improperly constituted.

In light of structural remediation's deficiencies, courts have three choices. First, they can alter structural remedies to correspond with the Court's description of substantive norms and regulated parties' interest in vindicating them. To this end, I discuss possible remedial reforms, most of which present their own difficulties. Second, courts can candidly recognize that remedial limitations constrict the meaning of an underlying safeguard. This option would allow regulated parties to decide, with better information, whether structural protections are worth vindicating. Finally, courts might reconsider a matter closely related to the nature of the safeguard-whether regulated parties' "personal rights" or "interests" in the enforcement of structural safeguards should be less significant than the Court's decisions, at times, suggest. In particular, the sometimes awkward fit between systemic harms and key remedial values for regulated parties reveals that perhaps only the competing branches of government should be able to enforce structural safeguards.

This Article is limited in four key ways. First, despite criticizing the Court's recent separation-of-powers cases elsewhere, ${ }^{40} \mathrm{I}$ accept its doctrine here. My purpose is to explore whether judicial remedies under that doctrine provide insight into the true nature of structural safeguards and how these remedies should be enforced. Second, my inquiry, unlike those in related scholarship, ${ }^{41}$ considers regulated

39. The term "structural remedy" may connote injunctive relief in public-interest litigation, such as with judicial remediation of racial discrimination through school busing or of Eighth Amendment violations through judicial oversight of prison administration. I use the term here to refer only to remedies to cure structural violations based upon Articles II and III of the Constitution.

40. See, e.g., Barnett, Independent Agency, supra note 38, at 1350; Barnett, Appointment with Trouble, supra note 38, at 1464-69.

41. See, e.g., Gorod, supra note 16, at 906-10 (discussing the impact of judicial review on the legislative branch). 
parties' remedies through a theoretical lens that views a remedy's suitability primarily from a regulated party's vantage point rather than that of an affected branch of the federal government. I do not assert that such a lens is the only or best way through which to view these remedies; instead, it is a helpful yet overlooked tool for illuminating the propriety of structural remedies. Other values-such as limiting regulatory chaos and considering the proper role of the courts, which I mention where relevant-are also important when considering a remedy from other perspectives and defining the structural safeguard. Third, I recognize the limited number of structural challenges by regulated parties from which one can draw conclusions. Nonetheless, it is better to consider existing decisions to help improve remedies in this burgeoning area of litigation. Finally, although I consider three possible responses to insufficient structural remedies, I take no position as to the best response, leaving that issue for another day. My purpose is only to spur courts, scholars, and regulated parties to explore how inadequate structural remedies impact underlying norms and to consider key options.

This Article proceeds as follows. Part I briefly describes the Supreme Court's understanding of the three structural safeguards that I consider in this Article: Appointments Clause limits, presidential-supervision limits, and judicial-authority limits. Part II explains why remedial theory matters for those safeguards and considers the three key values that structural remedies should serve for regulated parties. Part III considers the effectiveness of structural remedies with regard to these critical desiderata in six decisions. Part IV considers how courts and scholars could respond to limited structural remedies.

\section{CORE StRuctural SAFEGUARDS}

Most constitutional litigation regarding the federal administrative state concerns three safeguards: required methods of appointment under the Appointments Clause, the President's implied power to remove executive officers under Article II, and the necessity of judicial determination of disputed issues under Article III. This Part briefly considers how the Court has approached each of these safeguards and regulated parties' relationships to them.

The Appointments Clause controls the installation of officers of the United States. ${ }^{42}$ In effect, the clause separates appointees into two groups: principal officers and inferior officers. Principal officers,

42. See U.S. CONST. art. II, $\S 2$. 
based on their lack of subordination to other officers and the comparative importance of their duties, ${ }^{43}$ must be nominated by the President and confirmed by the Senate. ${ }^{44}$ Inferior officers must be appointed in the same manner as principal officers or, at Congress's election, by the President alone, the heads of executive departments, or the courts of law. ${ }^{45}$ The Supreme Court has stated that these specific appointment mechanisms are not mere "etiquette or protocol." "46 Instead, they act as a "bulwark against one branch aggrandizing its power at the expense of another branch" 47 and "preserve[] ... the Constitution's structural integrity."48 The clause also prevents the distribution of the appointment power to numerous officials, thereby helping ensure that identifiable individuals receive the praise or blame for good or bad appointments. ${ }^{49}$

These limits on the appointment power inure to the benefit of not only the branches of government but also regulated parties. ${ }^{50}$ Of particular importance, the courts have resisted suggestions that only the executive branch (or its own delegates) should be able to challenge defective appointments through quo warranto proceedings. ${ }^{51}$

43. See Edmond v. United States, 520 U.S. 651, 661-62 (1997); see also Intercollegiate Broad. Sys., Inc., v. Copyright Royalty Bd., 684 F.3d 1332, 1337-38 (D.C. Cir. 2012) (noting uncertainty under Supreme Court jurisprudence of whether proper inquiry considers subordination and importance), cert. denied, 133 S. Ct. 2735 (U.S. May 28, 2013) (No. 12-928).

44. U.S. CONST. art. II, $\S 2$.

45. Id.

46. Ryder v. United States, 515 U.S. 177, 182 (1995) (quoting Buckley v. Valeo, 424 U.S. 1, 125 (1976) (per curiam)).

47. Id. (quoting Freytag v. Comm'r, 501 U.S. 868, 878 (1991)). The power to appoint heads of executive and independent agencies can be very meaningful. Professor Glen Robinson has argued that independent agencies' agendas "fit closely with presidential programs in the Ford, Carter, and Reagan administrations and yet did not require close presidential control of the direction of agency decisions. Selective presidential intervention through appointments ... proved remarkably effective." Glen O. Robinson, Independent Agencies: Form and Substance in Executive Prerogative, 1988 DUKE L.J. 238, 250.

48. Freytag v. Comm'r, 501 U.S. 868, 878 (1991).

49. See id.

50. See Ryder, 515 U.S. at 182; see also Steven J. Duffield \& James C. Ho, Comment, The (Still) Illegal Appointment of Bill Lann Lee, 3 TEX. REV. L. \& POL. 403, 411 (1999) (noting that appointments that require senatorial confirmation "protect[] citizens by providing an added check against unwarranted government intrusion, ensuring that individuals are not vested with the enormous power of the federal government unless approved of by both the President and the Senate").

51. See Andrade v. Lauer, 729 F.2d 1475, 1496-97 (D.C. Cir. 1984); see also Kathryn A. Clokey, Note, The De Facto Officer Doctrine: The Case for Continued Application, 85 COLUM. L. REV. 1121, 1132 (1985) ("Andrade faults the de facto officer doctrine for 
Another key structural safeguard concerns the President's power to supervise executive officers. Although Article II says nothing expressly about the President's removal power, ${ }^{52}$ the Court has understood the "executive power" to carry with it a measure of presidential authority to remove executive officers, whether for any reason or only for some form of good cause.$^{53}$ The removal power is a safeguard that prevents the diffusion of authority that "would greatly diminish the intended and necessary responsibility of the chief magistrate himself." 54 Indeed, the Court has referred to the President's supervisory powers over the administrative state as "perhaps the key means" of preventing encroachment from the other branches on executive authority. ${ }^{55}$

The class of plaintiffs seeking to vindicate the President's supervisory powers has been expanding. Officials whom the President had removed have long brought, and prevailed in, challenges to the President's supervisory power by obtaining back pay. ${ }^{56}$ Members of other branches of government, too, have prevailed in Article II-based challenges to legislation. ${ }^{57}$ But more recently, regulated parties have

taking insufficient account of 'the public interest in enforcing legal norms concerning eligibility and appointment to office'...."). Then-Judge Ruth Bader Ginsburg joined the unanimous opinion in Andrade. See Andrade, 729 F.2d at 1478.

52. See, e.g., Free Enter. Fund v. Pub. Co. Accounting Oversight Bd., 130 S. Ct. 3138 , 3166 (2010) (Breyer, J., dissenting) (citing Ex parte Hennen, 38 U.S. (13 Pet.) 230, 258 (1839)); Morrison v. Olson, 487 U.S. 654, 690 n.29 (1988).

53. Free Enter. Fund, 130 S. Ct. at 3146-47.

54. Id. at 3164 (quoting THE FEDERALIST NO. 70 (Alexander Hamilton)).

55. Id. at 3157.

56. See Wiener v. United States, 357 U.S. 349, 350-51, 356 (1958); Humphrey's Ex'r v. United States, 295 U.S. 602, 619, 632 (1935). Presumably, the removed officer could recover money damages under the Tucker Act, 28 U.S.C. \$ 1491 (2012). See Tracey A. Hardin, Note, Rethinking Independence: The Lack of an Effective Remedy for Improper For-Cause Removals, 50 VAND. L. REV. 197, 200, 204 (1997). The remedy for an unlawful removal-an award of back pay-generally satisfies the four remedial values. When an officer is removed improperly, the President has failed to comply with an implied or express statutory requirement that limits his or her removal power in a constitutional manner. The monetary award can substantially compensate the removed officer and likely provide sufficient incentive to litigate the matter if the compensation is significant. The President's improper removal can also lead to deterrence because of the political price that the President may pay for the removal. See Rachel E. Barkow, Insulating Agencies: Avoiding Capture Through Institutional Design, 89 TEX. L. REV. 15, 30 (2010) (noting how "'removal is a doomsday machine'... for presidents" (quoting Paul R. Verkuil, Jawboning Administrative Agencies: Ex Parte Contracts by the White House, 80 ColuM. L. REV. 943, 957 (1980))); accord Nina A. Mendelson, Another Word on the President's Statutory Authority over Agency Action, 79 FORDHAM L. REV. 2455, 2477 (2011) (“[T]he agency official retains leverage in a particular case to inflict political costs on the President by resigning in protest or forcing the President to fire her.").

57. See Bowsher v. Synar, 478 U.S. 714, 719 (1986). 
brought challenges based on the President's removal power. ${ }^{58}$ The Court has not expressly stated that the President's supervisory powers exist to benefit regulated parties. It has, nonetheless, permitted regulated parties to challenge restrictions upon the President's supervisory powers even in direct opposition to the government's position in litigation and recognized an implied right of action under the Constitution to do so..$^{59}$

Finally, the Court has moved to prevent incursions into the judiciary's own constitutional domain. Article III provides that " $[\mathrm{t}] \mathrm{he}$ judicial Power of the United States, shall be vested in one supreme Court, and in such inferior Courts as the Congress may from time to time ordain and establish" and further provides salary protections and presumptive life tenure for federal judges. ${ }^{60}$ The Court has referred to separation of powers in the Article III context as "a prophylactic device, establishing high walls and clear distinctions because low walls and vague distinctions will not be judicially defensible in the heat of interbranch conflict." ${ }^{16}$ These walls also serve as an "inexorable command" 62 to ensure that the judiciary is independent from the other branches by not having to "curry[] favor" with either the legislative or executive branch. ${ }^{63}$

Notwithstanding Article III's protection for the courts, the Court has emphasized that the article serves "primarily personal, rather than structural, interests." ${ }^{64}$ It achieves this goal by ensuring that officials insulated from political pressures are assigned the power "to say what the law is." ${ }^{65}$ The Court has even spoken of regulated parties' interests as "personal right[s]" under Article III. ${ }^{66}$

58. See, e.g., Free Enter. Fund, 130 S. Ct. at 3146-47; Morrison v. Olson, 487 U.S. 654, 659-60 (1988).

59. See Free Enter. Fund, 130 S. Ct. at 3151 n.2; cf. Krent, supra note 38, at 2438 ("The President's Article II powers of appointment and removal are designed not merely to augment executive power, but to protect individual liberty."); accord Harold J. Krent, Fragmenting the Unitary Executive: Congressional Delegations of Administrative Authority Outside the Federal Government, 85 Nw. U. L. REV. 62, 74 (1990); see also Bond v. United States, 131 S. Ct. 2355, 2365 (2011) ("The structural principles secured by the separation of powers protect the individual as well.").

60. U.S. CONST. art. III, $\S 1$.

61. Plaut v. Spendthrift Farm, Inc., 514 U.S. 211, 239 (1995) (concerning legislation that sought to reopen final judgments).

62. N. Pipeline Constr. Co. v. Marathon Pipe Line Co., 458 U.S. 50, 58 (1982) (plurality opinion).

63. Stern v. Marshall, 131 S. Ct. 2594, 2609 (2011).

64. CFTC v. Schor, 478 U.S. 833, 848 (1986).

65. Plaut, 514 U.S. at 218 (quoting Marbury v. Madison, 5 U.S. (1 Cranch) 137, 177 (1803)).

66. Schor, 478 U.S. at 848 . 
The Court's analytical methods reinforce the idea that all of these safeguards are central to administrative structure. First, the Court's structural jurisprudence has relied increasingly upon formal analysis ${ }^{67}$ ignoring or minimizing functional critiques or problems that Congress encounters when establishing administrative entities. ${ }^{68}$ The Court has indicated that formal rules provide prophylactic devices that better protect the competing branches because functional inquiries may lead courts to view transgressions, in isolation, as minor or necessary under the seemingly urgent circumstances that surround the particular structural innovation. ${ }^{69}$ By erecting formal doctrines, the Court thereby ignores concerns (such as regulated parties' "capture" of the administrative agencies that are meant to regulate them $^{70}$ or certain entities' comparative subject-matter or other administrative advantage $^{71}$ ) that may have caused Congress to fashion the administrative state in other ways. In short, the Court uses formalism, in its view, to strengthen separation-of-powers safeguards themselves at the expense of competing concerns.

67. See, e.g., Barnett, Independent Agency, supra note 38, at 1367-69 (discussing the Court's formalist analysis of the President's removal power); Krotoszynski, Jr., supra note 38, at 1602; Ross E. Wiener, Inter-Branch Appointments After the Independent Counsel: Court Appointment of United States Attorneys, 86 MINN. L. REV. 363, 405 (2001) (noting a more formal analytical turn under the Appointments Clause); Ralph Brubaker, Article III's Bleak House (Part II): The Constitutional Limits of Bankruptcy Judges' Core Jurisdiction, 31 BANKR. L. LETTER No. 9, Sept. 2011, at 1, 6 (2011) (discussing formal analysis of Article III limits).

68. See generally Free Enter. Fund v. Pub. Co. Accounting Oversight Bd., 130 S. Ct. 3138, 3164-84 (2010) (Breyer, J., dissenting) (advocating against the formal view taken by the Court); Bowsher v. Synar, 478 U.S. 714, 759-75 (1986) (White, J., dissenting) (discussing the formalistic view taken by the Court).

69. See Plaut, 514 U.S. at 239 ("But the doctrine of separation of powers is a structural safeguard rather than a remedy to be applied only when specific harm, or risk of specific harm, can be identified. In its major features (of which the conclusiveness of judicial judgments is assuredly one) it is a prophylactic device, establishing high walls and clear distinctions because low walls and vague distinctions will not be judicially defensible in the heat of interbranch conflict."); see also Rachel E. Barkow, Separation of Powers and the Criminal Law, 58 STAN. L. REV. 989, 1001 n.48 (2006) (collecting academic justifications for formalism in separation-of-powers challenges, most of which turn on the importance of having prophylactic protections).

70. Lisa Schultz Bressman \& Robert B. Thompson, The Future of Agency Independence, 63 VAND. L. REV. 599, 614 (2010) ("Congress established the [PCAOB] as an entity within an independent agency, the SEC, to avoid capture by the accounting industry.").

71. See Stern v. Marshall, 131 S. Ct. 2594, 2628-29 (2011) (Breyer, J., dissenting) (arguing that bankruptcy courts could constitutionally decide certain common-law claims because, among other reasons, Congress could reasonably seek to allow more complete resolution of debtors' claims in centralized proceedings). 
Second, the irrelevance of the harmless error doctrine and the use of counterfactual scenarios in structural litigation should render judicial remediation of structural violations more likely and thereby signify the structural safeguards' importance. Courts can limit remedies for constitutional violations by turning either to the harmless error doctrine, which requires a showing of actual prejudice for judicial remediation, or to likely counterfactual scenarios, which consider whether the regulated party would likely be in the same place even had no constitutional violation occurred. For instance, before suppressing evidence for Fourth Amendment violations, courts will consider both actual harm to the challenging criminal defendant or counterfactuals to determine whether the police would "inevitably" have legally discovered evidence that, in fact, was illegally obtained..$^{72}$ But the courts have held that these doctrines that limit judicial remedies have little, if any, relevance to structural violations. ${ }^{73}$ By ignoring questions of harm in the structural context, the courts signal that a remedy should be more easily forthcoming for structural violations. As I discuss in more detail in Part II.A, with the availability of a more meaningful remedy comes a more meaningful right. $^{74}$

Yet, despite these safeguards' exalted place in administrative and constitutional law, courts have spent little time considering how to remedy structural violations for regulated parties who assert successful challenges. This lack of consideration may arise from the unclear nature of regulated parties' relationship with the structural safeguards. In those rare instances when the Court describes the regulated parties' concern in the safeguard, it sometimes speaks of a safeguard as establishing "personal rights" personal "interests." 76 The Court has suggested (if not held) that regulated parties have "implied private right[s] of action directly

72. See, e.g., United States v. Garcia, 496 F.3d 495, 505 (6th Cir. 2006) (citing Nix v. Williams, 467 U.S. 431, 443 n.4 (1984)) ("We nonetheless affirm the admissibility of the pager because it would inevitably have been lawfully discovered and, in any event, the district court's denial of the motion to suppress the pager was harmless error.").

73. See Free Enter. Fund, 130 S. Ct. at 3155-56 (rejecting the dissent's functional analysis); Ryder v. United States, 515 U.S. 177, 184 n.4, 186 (1995); see also Landry v. FDIC, 204 F.3d 1125, 1130-31 (D.C. Cir. 2000) (holding that a showing of harm was not required for a structural violation to exist); Andrade v. Lauer, 729 F.2d 1475, 1495 (D.C. Cir. 1984) ("The [Appointments] [C]lause would be a nullity if it could be assumed that these very officials would in fact have been properly appointed and (especially) confirmed by the Senate.").

74. See Levinson, supra note 32, at 888; infra Part II.A.1.

75. See CFTC v. Schor, 478 U.S. 833, 848 (1996).

76. See id. 
under the Constitution ... under the Appointments Clause or separation-of-powers principles," including the principles under Article II, that entitle them to unspecified equitable relief. ${ }^{77}$ In the context of 42 U.S.C. $\$ 1983,{ }^{78}$ the Court has recognized a key difference between "rights" and "interests" (or "benefits") that influences the availability of remedies in important ways. ${ }^{79}$ But the Court has not explored whether there is a difference between "rights" and "interests" in the separation-of-powers context and whether that difference might have remedial consequences.

This Article does not seek to resolve the relationship between regulated parties and structural safeguards. It refers to the regulated parties' concerns for structural safeguards or norms as "rights" and "interests" interchangeably without intending for the terms to take on some additional significance. The important point here is that the Court has not paused to consider how constitutional rules that address the relations of the branches of government intersect with private parties who invoke these rules and with the remedies those private parties seek. Yet considering the meaningfulness and adaptability of structural remedies from the regulated party's perspective may inform the descriptive and normative nature of the party's interest in and relationship to the safeguards.

\section{PROPER REMEDIES}

Remedial considerations are important for two key reasons. The first reason is obvious but often overlooked: remedies are what litigants get in a concrete sense if their lawsuits are successful. Many litigants may care only marginally, if at all, about the boundaries of administrative structures or these structures' effect on constitutional or administrative law theory. But they do care about altering agency structures in ways that further their own interests. The second reason is that substantive norms and remedies are so closely bound together that it is all but meaningless to consider one without the other. ${ }^{80}$

\section{A. The Importance of Remedies}

Scholars may view remedies as "the banausic sphere of policy, pragmatism, and politics." ${ }^{\text {"1 }}$ But litigants generally care only about

77. Free Enter. Fund, 130 S. Ct. at 3151 n.2 (quoting the United States' brief).

78. 42 U.S.C. $\$ 1983(2006)$.

79. See Gonzaga v. Doe, 536 U.S. 273, 283 (2002).

80. See Levinson, supra note 32, at 857.

81. Id. 
substantive norms that have practical value to them. Without an adequate remedy, a norm loses its value and is not worth vindicating. ${ }^{82}$ For instance, the mere pronouncement of a norm through a declaratory judgment may be less valuable than a prohibitory injunction that limits administrative action, leaving litigants less incentive to vindicate that norm. If affected parties have no incentive to enforce a norm, that norm may cease to operate.

Remedies also give shape and meaning to substantive law. The U.S. Constitution is nearly silent as to how courts or Congress should remedy constitutional violations. ${ }^{83}$ This silence can be beneficial, giving judges room to maneuver as they consider ideals that animate constitutional rights and interests in a practical, political space. Yet it also requires courts (and perhaps Congress) to accept the responsibility of considering what makes a remedy proper. Remedies become "the means by which the abstractions of the substantive law are translated into concrete terms." 84

\section{Rights and Remedies' Interdependence}

In examining certain constitutional civil rights, Professor Daryl Levinson concluded that this translation does more than make hortatory rhetoric comprehensible. ${ }^{85}$ Remedies, in his view, also modify the meaning of norms or rights by narrowing or expanding them. ${ }^{86}$ For instance, the Court's early equal-protection decisions after Brown v. Board of Education ${ }^{87}$ could be read as applying to de jure and de facto discrimination. But the Court used remedies, such as with school-busing schemes' temporal length and geographic reach, to limit an equal-protection right to de jure discrimination. ${ }^{88}$ Remedies may even come to define the right itself. For example, faced with the vague Eighth Amendment prohibition on "cruel and unusual" punishment as applied to prison conditions, courts and litigants have used past judicial remedies-such as limits on the number of inmates housed in a room as established in a consent decree-as constitutional benchmarks that apply to similar litigation,

82. See id. at 887 (referring to the "cash value of a right" as dependent on the remedy).

83. See Hill, supra note 34, at 1118. One notable exception is the reference to habeas corpus. See id. at 1118 n.42.

84. Wright, supra note 33, at 377; see also Levinson, supra note 32, at 858 (discussing the relationship of rights and remedies).

85. See Levinson, supra note 32, at 873-74.

86. See id.

87. 347 U.S. 483 (1954).

88. See Levinson, supra note 32 , at $884-85$. 
whereby it is "cruel and unusual" to exceed those numbers in the future. ${ }^{89}$ This inversion of remedy and rights occurs because "the only way to get a sense of which prison conditions are [cruel and unusual] is to see what kinds of concrete changes are required by remedial orders." ${ }^{90}$ Because remedies can, in various ways, define substantive norms, they are, to use Levinson's term, in "equilibrium," such that neither is more important than the other. ${ }^{91}$

Of particular importance to the subject at hand is a critical point about the right-remedy relationship: as remedies narrow in scope or decrease in number, rights lose value to litigants who seek to enforce them. ${ }^{92}$ Yet limiting remedies can have virtues. The Court, for example, has understandably taken account of federalism, judicial competence, and political resistance when fashioning constitutional remedies. ${ }^{93}$ Using remedies to limit a right's practical effect allows courts to consider competing values and costs in achieving as much of a remedy as is possible for a particular norm. ${ }^{94}$ In the administrative context, for instance, courts can balance the need for litigating parties to have incentives to seek redress against either the chaos that could arise from entirely stopping an agency from functioning or concerns about judicial competence in redesigning arms of the federal government. ${ }^{95}$ The balancing of such competing considerations may also permit courts to expand remedies later as practical realities change. ${ }^{96}$

Expanding remedies also alters rights, but not necessarily in ways that litigants would prefer. Although an expansive remedy may seek to ensure that an underlying norm is fully vindicated, such a remedy can lead to underenforcement of substantive norms. ${ }^{97}$ A remedy that is too powerful may face legitimate or illegitimate resistance or demand such an investment of judicial resources that courts avoid finding a violation in the first place. ${ }^{98}$ For instance, courts could invalidate entire agencies—such as the SEC - based on structural

89. See id. at $879-80$.

90. Id. at 880 .

91. See id.

92. See id. at 888; see also Philip Hamburger, More Is Less, 90 VA. L. REV. 835, 837 (2004) ("Nonetheless, the danger [that an expanded right may ultimately become less available] may be inherent in every attempt to expand a right, for at some point, as the definition of a right is enlarged, there are likely to be reasons for qualifying access.").

93. See, e.g., Gewirtz, supra note 34, at 589-628; Levinson, supra note 32, at 873-84.

94. See Wright, supra note 33 , at 377-81.

95. See Gewirtz, supra note 34, at 598-608.

96. See id.

97. See Levinson, supra note 32, at 866-70.

98. See Gewirtz, supra note 34, at 589-91. 
deficiencies. But aware of the practical chaos that such a remedy would create, courts would likely narrow the underlying structural safeguard so as to rarely find a violation. ${ }^{99}$

\section{Rights and Remedies' Independence}

Despite the importance of the relationship between rights and remedies, Levinson's remedial-equilibrium paradigm may be less salient in the context of structural challenges to the federal administrative state. Oftentimes these structural challenges are based on more formally defined rights than those imposed by the Eighth and Fourteenth Amendment rights to which Levinson refers. For instance, the Appointments Clause requires that principal officers be appointed in one way and that inferior officers be appointed in one of four ways. ${ }^{100}$ Although there is uncertainty over, say, the nature of a department or an officer, the nature of the constitutional requirement is relatively clear because the Constitution provides exactly how the appointment must occur. ${ }^{101}$ Likewise, the Court has come to express the nature of the President's supervisory powers in formal terms based on the kind of protections that an executive-branch officer has from the President's (or other officer's) at-will removal. ${ }^{102}$ The boundaries of required executive supervision often fluctuate within the Court's jurisprudence, but the constitutional requirement can be stated in relatively clear terms of protection from at-will removal. Unlike the scenarios that Levinson considers, the presence of a structural violation, as opposed to its importance, can be established without regard to the remedy: whether that remedy is the invalidation of the agency itself, invalidation of a specific agency action, or invalidation of the offending statutory provision.

Thinking of rights and remedies as independent concepts ${ }^{103}$ can also be practical and allow legislatures room to address remedial

99. See Levinson, supra note 32, at 889, 913; see also infra Part IV.B (discussing how courts have limited the Article III safeguard as it applies to agencies).

100. See U.S. CONST. art. II, § 2, cl. 2; supra text accompanying notes $42-45$.

101. See U.S. CONST. art. II, § 2, cl. 2.

102. See generally Barnett, Independent Agency, supra note 38, at 1367-69 (discussing the Court's formalist analysis of the President's removal power and the importance of the language in protections from removal).

103. See, e.g., Wesley Newcomb Hohfeld, Fundamental Legal Conceptions as Applied in Judicial Reasoning, 26 YALE L.J. 710, 736 (1917) ("Whether he can make the seizure himself ... may be important as to remedy, but does not affect his ultimate and essential right.”). 
concerns. ${ }^{104}$ Certain scholars have sought to separate a right from its remedy to ensure that courts have full power to define rights à la Marbury v. Madison ${ }^{105}$ while recognizing Congress's power to help define suitable remedies. ${ }^{106}$ They recognize that creating remedies requires balancing different interests, including fiscal and administrative costs that have a significance that is independent from the norm itself. ${ }^{107}$ Fact-bound remedial considerations such as these may be more suitable for legislatures than courts. ${ }^{108}$

This insight is important because it recognizes that Congress can and should play a role in fashioning remedies. As Professor (and former Acting U.S. Solicitor General) Walter Dellinger has argued in the context of Fourth Amendment violations, the means of enforcing "constitutional right [s] should be left with Congress unless, in the absence of judicial action, the right in question would be so wanting of remedies as to render it a mere form of words." ${ }^{109}$ Rights can be realized in different ways, each with its own set of costs, effectiveness, and symbolic consequences. As explained below, ${ }^{110}$ viewing Congress as a partner in structural remediation (and consequently defining the safeguard) may provide useful play in the joints as structural remedies are fitted to structural constitutional violations.

\section{B. Key Remedial Values}

Although "a perfect remedy is a frequent illusion," 111 a remedy can qualify as "good" only if it responds to relevant underlying values. ${ }^{112}$ In the context of structural remediation, however, courts and scholars have often failed to consider values that the remedy

104. See Samuel L. Bray, Announcing Remedies, 97 CORNELL L. REV. 753, 757 (2012) (noting that Levinson's theory can be useful but "overwhelm[ing]" and limiting its application for purposes of his thesis).

105. 5 U.S. (1 Cranch) 137 (1803).

106. See, e.g., Gewirtz, supra note 34 , at 678 .

107. See Dellinger, supra note 34, at 1556.

108. See id.

109. Id. at 1536 (internal quotation marks omitted).

110. See infra Part IV.A.3.

111. Gewirtz, supra note 34, at 591-92.

112. Cf. Wright, supra note 33 , at 386 (recognizing that courts should look past the technical rules of legal and equitable remedies and instead consider the "relevant social policies"). Professor Wright identified five remedial principles or purposes that remedies are intended to serve. See id. at 377-80. But these purposes or principles, in some instances, are instead merely descriptions of the nature of the remedy. For instance, he identifies a schedule of remedies as a purpose. Id. But a schedule of remedies-in which a statute provides the proper consideration for the violation of different rights or harms-is a kind of remedial scheme that may have many purposes, such as punishment, deterrence, and compensation. $I d$. 
should attempt to satisfy. ${ }^{113}$ Those values are mentioned, if at all, only in passing. ${ }^{114}$ Or the court articulates "a rather variable application of the vague equitable maxim that 'the nature of the ... remedy is to be determined by the nature and scope of the violation' "115 or it states that "rights should find vindication in an effective remedy." 116

To consider the success and failings of remedies for separationof-powers violations, I consider the three remedial values I have encountered most in scholarship and case law concerning remedies for individual parties: (1) compensation for past harm (and a related sub-value of prospective enforcement of the norm), (2) incentives to seek redress of a violated norm, and (3) deterrence of future violations. ${ }^{117}$ I turn to private-law remedial practice (and certain public-law remedies) to put structural remedies in context and to suggest how structural remedies for prevailing regulated parties can be viewed as succeeding or failing. I do not contend here that remedies should work exactly the same way in all private- and publiclaw contexts or that no other considerations-such as regulatory chaos or separation-of-powers concerns-are relevant. Indeed, I recognize that these three most significant, traditional remedial values for private parties often rest awkwardly with structural remedies, suggesting that satisfactory remedies might be difficult to fashion and thus that courts should perhaps reconsider the nature of the underlying safeguards. ${ }^{118}$

\section{Compensation for Past Harm and Prospective Enforcement}

Perhaps the most important remedial values are compensation for past harm and prospective enforcement. I discuss these values

113. See, e.g., Gewirtz, supra note 34, at 591; Wright, supra note 33, at 376-81.

114. See Gewirtz, supra note 34, at 591.

115. Nagel, supra note 34, at 712.

116. Sturm, supra note 31 , at 1378.

117. Other remedial values include personal vindication of the right, punishment, or restitution (focusing on the return of wrongful profits, not compensation for loss). See DAN B. DOBBS, HANDBOOK ON THE LAW OF REMEDIES 135-37 (1st ed. 1973). As I suggest later, punishment is not likely a relevant value in most structural contexts. See infra note 203. Likewise, personal vindication, in my view, is tied to litigation incentive and compensation. The mere pronouncement of a right may have some value (especially for certain dignitary harms), but it is almost certainly less valuable (and vindicated less fully) than an infringed right for which the law gives a more meaningful remedy. See DoBBS, supra, at 135 (referring to the use of nominal damages to vindicate "technical right[s]"). Vindication, therefore, has little value in and of itself and rarely occurs without the other values' presence. I have also not considered restitution here because of the difficulty of valuing how the government or a particular branch of government has "profited" from a structural defect. My focus is on the prevailing party's injury.

118. See infra Part IV.C. 
together in this Section because of their close relationship to one another in the structural context. Prospective enforcement through injunctive relief is, of course, common in public-law litigation and provides the prevailing party, in most cases, with either some substantive benefit or procedures that are more likely than structural reforms to influence an agency's substantive decision. ${ }^{119}$ Money damages, however, are conspicuously absent in most constitutional challenges against the federal government, thereby limiting compensation to a prevailing party for past harm. ${ }^{120}$ Courts, nonetheless, can partially achieve both of these values in the structural context without money damages by attempting to compensate through equitable relief. ${ }^{121}$

Compensation for an inflicted injury is likely the most familiar purpose of legal remedies. ${ }^{122}$ Compensation can take different forms but generally manifests itself through money damages. ${ }^{123}$ In tort law, money damages are typically tied to harm to property, medical bills, pain and suffering, lost wages or profits, and the like. ${ }^{124}$ Compensatory money damages for breach of contract usually look to expectation damages, which are based on what the non-breaching party expected to receive from a performed contract. ${ }^{125}$ The underlying notion is that monetary damages in both contexts will make the victim whole, meaning that the law-to the extent possible-places the victim in the place where he or she would have

119. See infra Part II.B.2. For example, many procedural challenges will concern parties' rights under the Administrative Procedure Act. See 5 U.S.C. $\S \S 551-559$ (2012). These procedural challenges could be based upon the failure of the agency to engage in required notice-and-comment rulemaking, see id. $\$ 553(\mathrm{~b})(3)$, the failure of the agency to provide sufficient notice for a proposed rule, see id. $\S 553(\mathrm{~b})$, the failure of the agency to provide a sufficient explanation of a final rule's basis and purpose, see id. $\S 553(\mathrm{c})$, or the failure of the agency to abide by the procedural requirements for formal adjudication, see $i d$. $\S \S 554,556$. The agency's failure to abide by these procedural requirements can indicate a failure to obtain or consider relevant comments or testimony. The agency's failure to do so can lead to a different outcome. See Chocolate Mfrs. Ass'n v. Block, 755 F.2d 1098, 1106-07 (4th Cir. 1985) (invalidating an agency rule that sought to prohibit beneficiaries of the Women, Infants and Children Program ("WIC") from purchasing chocolate milk because of inadequate notice to interested parties); see also U.S. Dep't of Agric., Benefits and Services: WIC Food Package, FOOD \& NUTRITION SERviCE, http://www.fns.usda.gov/wic/benefitsandservices/former-foodpkgmilkfaqs.HTM (last visited Dec. 28, 2013) (noting that chocolate milk continues to be WIC-eligible).

120. See infra text accompanying notes 128-46.

121. See Wright, supra note 33, at 377-78.

122. See, e.g., Gewirtz, supra note 34, at 592; Wright, supra note 33, at 377.

123. See Wright, supra note 33 , at 377.

124. See DOBBS, supra note 117 , at 540-51.

125. See E. Allan FARnsworth, CONTRACTS 730-33 (4th ed. 2004). 
been had no violation or breach occurred. ${ }^{126}$ Constitutional litigation, too, often focuses on compensatory values in the context of $\S 1983$ litigation and actions brought directly under the Constitution itself. ${ }^{127}$

No matter how uncomfortably the compensation value rests within constitutional challenges generally, it may rest even less comfortably within structural litigation for two main reasons. First, a prevailing party's loss caused by a structural defect may be difficult to value, which renders compensation difficult to achieve. ${ }^{128}$ Assume, for instance, that a regulated party against which an agency has successfully asserted an enforcement proceeding demonstrates that the agency is not sufficiently subject to the President's supervision. The pecuniary damage to the regulated party is difficult to measure because it seeks to quantify the harm caused by having an agency that was not sufficiently accountable to the President. Perhaps one should envision a world in which a properly supplicant agency would or would not have brought an enforcement proceeding or taken some other action because of either differing discretion or changes to the substantive regulatory policy. But numerous scholars have questioned the practical significance of the President's power to remove officers, ${ }^{129}$ rendering it speculative to suggest that a properly supervised agency would have acted any differently. If so, the injury to the regulated party is difficult to discern and, like emotional harms,${ }^{130}$ difficult to measure in monetary terms. This is not to say that all other public-law or even private-law harms are easy to value. But structural challenges will almost always present valuation and

126. See U.C.C. $\$ 1-305($ a) (2005); DoBBS, supra note 117 , at 136 ("[T]he main purpose of the damages award is some rough kind of compensation for the plaintiff's loss."); Wright, supra note 33, at 377 (describing the "indemnity" or compensation principle).

127. See, e.g., John C. Jeffries, The Right-Remedy Gap in Constitutional Law, 109 YALE L.J. 87, 89 (1999); see also Monell v. Dep't of Soc. Servs., 436 U.S. 658, 663, 690 (1978) (permitting compensatory awards for a municipality's violation of constitutional rights that are based on the municipality's policy or custom and overruling contrary holding in Monroe v. Pape, 365 U.S. 167 (1961)).

128. See Bray, supra note 104, at 763 (citing Ronen Avaraham, Putting a Price on Painand-Suffering Damages: A Critique of the Current Approaches and a Preliminary Proposal for Change, 100 Nw. U. L. REV. 87, 94-96 \& n.43 (2006)).

129. See, e.g., Barkow, supra note 56, at 30; Harold H. Bruff, Presidential Power Meets Bureaucratic Expertise, 12 U. PA. J. CONST. L. 461, 480-81 (2010); Jonathan L. Entin, Synecdoche and the Presidency: The Removal Power as Symbol, 47 CASE W. RES. L. REV. 1595, 1601-02 (1997); Jonathan L. Entin, The Removal Power and the Federal Deficit: Form, Substance, and Administrative Independence, 75 KY. L.J. 699, 777-81 (1987); Elena Kagan, Presidential Administration, 114 HARV. L. REV. 2245, 2273-74 (2001).

130. See Phillips v. Hunter Trails Cmty. Ass'n, 685 F.2d 184, 190 (7th Cir. 1982) ("Injuries [for mental and emotional distress] are by their nature difficult to prove."). 
causation difficulties even if, as in the case of emotional harms, those difficulties can sometimes be overcome.

Second, even if one presumes that the agency would not have taken a certain action in the absence of a structural defect, the case for pecuniary damages may be weaker than in other contexts because the judiciary, as in many other public-law contexts, can prevent much of the harm by providing prospective enforcement with an injunction. Agencies will typically require regulated parties to take particular actions, such as paying a fine or discontinuing a business practice. The court can avoid much of any resulting harm by staying or invalidating the agency's order or other action. ${ }^{131}$ By preventing the injury from occurring and enforcing the norm prospectively, the Court may render compensation for past harm less important. ${ }^{132}$

For any harm that remains uncompensated, a monetary remedy does not likely exist, whether the structural violations are deemed analogous to tort or contract. Although Congress has ensured under the Administrative Procedure Act ("APA") that a litigant can seek "relief other than money damages" against an agency and its

131. Indeed, invalidating an agency order or rule is the most typical remedy for an overreaching agency. See 5 U.S.C. §706(2) (2012). This is true whether the defect is procedural, see David B. Chaffin, Note, Remedies for Noncompliance with Section 553 of the Administrative Procedure Act: A Critical Evaluation of United States Steel and Western Oil \& Gas, 1982 DUKE L.J. 461, 464-65 ("Most courts sustaining such procedural challenges immediately invalidate the rule and remand the case to the agency with instructions to follow proper section 553 procedures."); id. at 465 n.23 ("Most courts use this remedy [of invalidation and remand] as a matter of course, seemingly without considering whether alternatives are available."), or substantive, see Glen Staszewski, Rejecting the Myth of Popular Sovereignty and Applying an Agency Model to Direct Democracy, 56 VAND. L. REV. 395, 395 (2003) ("When an agency fails to engage in reasoned decisionmaking during the lawmaking process, courts must invalidate the final rule and remand the matter to the agency for further consideration.").

132. To be sure, the regulated party likely incurred significant legal fees in regulatory investigations and proceedings. See, e.g., Key Tronic Corp. v. United States, 511 U.S. 809 , 811-12 (1994). Yet, despite some exceptions in administrative matters, courts typically ignore these costs as merely part of doing business or of living in a society with a functioning judiciary (and administrative state). See id. at 809; Gregory C. Sisk, The Essentials of the Equal Access to Justice Act: Court Awards of Attorney's Fees for Unreasonable Government Conduct (Part One), 55 LA. L. REV. 217, 233-34 (1995) (citing 5 U.S.C. § 504(a)(1) (1988)) (noting that the Equal Access to Justice Act permits recovery of attorneys' fees if the government's position is not substantially justified); Gregory C. Sisk, The Essentials of the Equal Access to Justice Act: Court Awards of Attorney's Fees for Unreasonable Government Conduct (Part Two), 56 LA. L. REV. 1, 191-200 (1995) (citing Harold J. Krent, Fee Shifting Under the Equal Access to Justice Act-A Qualified Success, 11 YALE L. \& POL'Y REV. 458, 500 (1993)) (noting the rarity of EAJA awards and limited effectiveness of the statute at realizing remedial purposes); John P. Stern, Note, Applying the Equal Access to Justice Act to Asylum Hearings, 97 YALE L.J. 1459, 1464 (1989) (noting that awards of attorney's fees under the EAJA are rare). 
officials ${ }^{133}$ Congress has generally retained its sovereign immunity from suits seeking monetary damages. ${ }^{134}$ The two significant statutes in which Congress has waived its sovereign immunity-the Federal Tort Claims $\mathrm{Act}^{135}$ for tort claims and the Tucker Act $^{136}$ for contract claims-are almost certainly inapplicable to nearly all regulated parties that assert structural challenges. ${ }^{137}$

Likewise, the courts have not created a cause of action for money damages against agency officials directly under the Constitution for structural violations. The Court has created direct causes of action under the Constitution in limited circumstances. In Bivens v. Six Unknown Named Agents of Federal Bureau of Narcotics, ${ }^{138}$ the Court created a direct cause of action against federal officials who violate the Fourth Amendment. ${ }^{139}$ Although Bivens focused on the Fourth Amendment, a "Bivens action" has come to refer to all actions for money damages brought directly under the Constitution. ${ }^{140}$ The Court has created Bivens actions under the Fifth Amendment ${ }^{141}$ and the Eighth Amendment. ${ }^{142}$ But the Court has since responded cautiously "to suggestions that Bivens be extended into new contexts." 143 In particular, the Court unanimously refused to create a Bivens action against federal agencies themselves. ${ }^{144}$

133. 5 U.S.C. $\$ 702(2012)$.

134. See ERWIN CHEMERINSKY, FEDERAL JURISDICTION 614-16 (4th ed. 2003).

135. 28 U.S.C. $\$ 2674$ (2012).

136. Id. at $\S 1346$.

137. See Loveladies Harbor, Inc. v. United States, 27 F.3d 1545, 1554 (Fed. Cir. 1994) (en banc) (citing United States v. Connolly, 716 F.2d 882, 885 (Fed. Cir. 1983) (discussing the Tucker Act)), overruled by United States v. Tohono O'Odham Nation, $131 \mathrm{~S}$. Ct. 1723 (2011), as stated in U.S. Home Corp. v. United States, 108 Fed. Cl. 191, 194 (Fed. Cl. 2012); CHEMERINSKY, supra note 134, at 621 (citing Dalehite v. United States, 346 U.S. 15, 27 (1953) (discussing the Federal Tort Claims Act)).

138. 403 U.S. 388 (1971).

139. Id. at 389.

140. See Matthew S. Tripolitsiotis, Note, Grosh v. Ramirez, the Warranty Requirement, and Qualified Immunity, 6 U. PA. J. CONST. L. 1179, 1182 n.30 (2004).

141. See Davis v. Passman, 442 U.S. 228, 230 (1979).

142. See Carlson v. Green, 446 U.S. 14, 16 (1980). The Court has assumed, but never held, that a Bivens action may be grounded in the First Amendment. See Ashcroft v. Iqbal, 556 U.S. 662, 675 (2009) (citing Bush v. Lucas, 462 U.S. 367 (1983)).

143. Schweiker v. Chilicky, 487 U.S. 412, 422 (1988).

144. See FDIC v. Meyer, 510 U.S. 471, 486 (1994). In Meyer, a federal agency terminated Meyer from his position as an officer of a failing thrift institution. Id. at 473 . Meyer asserted several claims, including a putative Bivens claim against the federal agency (and a federal officer) for due process violations. See id. at 474, 484. The Supreme Court held that Bivens actions are not cognizable against the federal agencies because: Bivens itself was an action against federal officers, see id. at 484-85; the extension of Bivens actions against an agency would allow parties to make an end-run around qualified immunity doctrines that protect federal officers, see id. at 485; and the threat of Bivens 
A Bivens action, moreover, may make little sense in a structuralchallenge context. The Court has stated that it will not extend Bivens when Congress has created an alternate, equally effective resolution mechanism or when other "special factors counsel[] hesitation." 145 "Special factors" (despite being ill-defined in case law) likely exist structural-challenge context. First, structural defects, by their very nature, usually infect the entire agency and thereby affect numerous agency actions and actors as opposed to a specific action, policy, or actor. Second, because a structural defect is usually not created by the agency itself or its actors, the agency officials should not be personally responsible (even if later indemnified by the federal government) for compensating the wronged party. Unlike other Bivens claims based on individual rights within the Bill of Rights, structural defects do not involve legal principles that often come into conflict with day-to-day agency actions, and thus the agency official would have little reason to be familiar with the nature of structural limitations. This is so because it is Congress (usually with the support of the President) that creates the agencies and any resulting structural defect. Given a Bivens action's close relationship to tort, the extension of Bivens to structural challenges would ignore the identity of the analogous tortfeasor and the causation between the putative tortfeasor's action and the inflicted harm. ${ }^{146}$

Despite the absence of a cause of action for money damages, courts can still validate the compensatory interest in other, albeit perhaps less complete and conventional, ways. Equitable relief, such as specific performance, can provide not only prospective enforcement but also compensation even in the tort context. ${ }^{147}$ For

actions unadorned by qualified immunity would lead to "a potentially enormous financial burden for the Federal Government." Id. at 486.

145. See Bivens v. Six Unknown Named Agents, 403 U.S. 388, 395-97 (1971). The Court has provided little guidance as to the "special factors," but it has denied Bivens actions when Congress has established alternative remedial mechanisms or the claims arise from military service. See CHEMERINSKY, supra note 134, at 600-04. Likewise, in Meyer, the Court deemed the potentially "enormous financial burden for the Federal Government" that could arise from allowing Bivens actions directly against federal agencies as a "special factor[] counselling hesitation." Meyer, 510 U.S. at 486 (internal citation omitted).

146. Cf. Hill, supra note 34 , at 1137. If a Bivens action did lie, the official would not likely be able to rely on immunity defenses. See Harlow v. Fitzgerald, 457 U.S. 800, 809 (1982); Butz v. Economou, 438 U.S. 478, 523 (1978). Qualified immunity, typically available to administrative officials, is available only to discretionary decisions. See Harlow, 457 U.S. at 818. Whether an agency is established properly does not involve a discretionary decision on the part of an agency official. See id.

147. See Lillian R. BeVier, Reconsidering Inducement, 76 VA. L. REV. 877, 908 (1990); Alan Schwartz, The Case for Specific Performance, 89 YALE L.J. 271, 271 (1979). 
instance, in a car-accident case in which the plaintiff suffered only property damage, a court could require the defendant to have the plaintiff's car repaired instead of requiring the defendant to pay money damages. ${ }^{148}$ Having the car repaired can make the plaintiff substantially whole in the same way as money can. Specific performance may also be very useful in an imperfect world by providing a compensatory remedy when valuation is difficult. ${ }^{149}$

Certain forms of equitable relief that are analogous to specific performance can serve a similar purpose in structural-defect cases. The most common remedy for unconstitutional action is injunctive relief to provide prospective enforcement of an underlying norm. ${ }^{150}$ As part of the equitable relief, a court faced with a structural defect could — and sometimes does ${ }^{151}$ - go further by requiring a wholly new proceeding, investigation, or other action before or by a properly established agency. ${ }^{152} \mathrm{~A}$ new proceeding before a properly configured agency compensates in part. As with a specific-performance remedy for breach of contract, the regulated party obtains all to which it was entitled under the "contract" between citizen and government that is the U.S. Constitution. Likewise, as with analogous tort remedies (for example, the return of an item that has been converted by the defendant), the regulated party is returned to substantially the same position that the party would have been in had the government not "wronged" the regulated party by establishing a structurally defective agency. ${ }^{153}$ The new proceeding ensures that the party receives the

148. See, e.g., DoBBS, supra note 117, at 135; Wright, supra note 33, at 378.

149. See FARNSWORTH, supra note 125 , at $747-48$.

150. See Preis, supra note 35, at 1-3.

151. See, e.g., Free Enter. Fund v. Pub. Co. Accounting Oversight Bd., 130 S. Ct. 3138, 3161-62 (2010); Intercollegiate Broad. Sys., Inc. v. Copyright Royalty Bd., 684 F.3d 1332, 1342 (D.C. Cir. 2012), cert. denied, 133 S. Ct. 2735 (U.S. May 28, 2013) (No. 12-928).

152. Perhaps sovereign immunity prohibits courts from awarding some form of specific performance or other injunctive relief, such as when the relief sought is equivalent to monetary damages. See Normandy Apartments, Ltd. v. U.S. Dep't of Hous. \& Urban Dev., 554 F.3d 1290, 1296-97 (10th Cir. 2009). But courts have awarded analogous relief when Congress has violated the Appointments Clause, see infra Part III, and, despite the general applicability of sovereign immunity, the Courts have a long history of awarding various forms of injunctive relief that may address the effects of past violations, see, e.g., Preis, supra note 35 , at 43-44, 48-50.

153. Although it is true that the prevailing party does not recover any compensation for attorneys' fees and other expenses that it incurred because of the actions taken by a structurally defective agency, these expenses are, as discussed above, those that the law generally does not deem compensable. See supra note 132. In the structural context, as in other constitutional challenges against the federal government, the equitable remedies can compensate only in part. 
structural safeguard's protection for all portions of an agency's decision-making process.

If, in contrast, the court does not require new proceedings, but instead only "cure[s]" future proceedings through the issuance of exclusively forward-looking injunctive relief, ${ }^{154}$ the remedy may prevent some future harm by enforcing the norm prospectively. But the remedy does not give the prevailing party that to which it was entitled in the first instance. It also does not stop any "tainted fruit" of the initial, defective proceedings from infecting future proceedings. Instead, future harms based on past structural defects may significantly affect regulated parties so long as the court gives the agency's past actions de facto validity. For example, a judicial remedy that provides de facto validity to the past actions of unconstitutionally installed officers but otherwise forbids the agency from promulgating future regulations or holding future adjudications - an actual remedy that the Court has employed ${ }^{155}$-would not compensate for past violations or even prevent those future harms that flow from a structurally defective administrative entity's past actions.

To be sure, courts often ignore or fail to fulfill the compensatory value when the United States has acted in an unconstitutional manner even outside the structural context. Based on prudential concerns, for example, courts provide only prospective injunctive relief to stop an ongoing constitutional or statutory violation, preventing future harm but not rectifying past wrongs. ${ }^{156} \mathrm{But}$, as is relevant to the other two values discussed below, the prevailing party obtains something substantive and meaningful in most non-structural cases (whether based on constitutional or administrative law). For example, the agency may be required to ignore a particular criterion, treat certain regulated parties similarly, or engage in certain procedures. These requirements can, but do not always, affect the agency's final decision and thereby are meaningful to the prevailing party. And even if compensation is uncommon in non-structural challenges, the failure to provide past compensatory relief is a recurring criticism of constitutional-remedial doctrine, ${ }^{157}$ a criticism that courts- through

154. See, e.g., Ryder v. United States, 515 U.S. 177, 184-86 (1995).

155. See infra Part III.B.2 (discussing the structural remedy in Buckley v. Valeo, 424 U.S. 1 (1976) (per curiam)).

156. See Preis, supra note 35 , at $1-3$.

157. See, e.g., Akhil Reed Amar, Of Sovereignty and Federalism, 96 YALE L.J. 1425, 1427 (1987) ("Whenever [governments] do act unconstitutionally, they must in some way undo the violation by ensuring that victims are made whole. In many cases, only governmental liability can provide this assurance."); see also Jeffries, supra note 127, at 
Bivens actions, school-busing cases seeking to eradicate "effects" of segregation, and affirmative-action cases—have oftentimes responded to in a robust way. ${ }^{158}$ In short, remedies for other constitutional violations do not establish that the compensatory value is irrelevant or unnecessary, only that it is often not fully realized.

\section{Incentives to Pursue Redress}

Meaningful remedies should provide wronged parties with incentives to enforce their interests ${ }^{159}$ because otherwise the underlying norm has no traction in the real world. ${ }^{160}$ In one of its more recent structural-defect decisions, the Supreme Court recognized that a remedy must provide sufficient incentive to litigate structural challenges. ${ }^{161}$ Without such an incentive, the wronged party will be unlikely to seek to vindicate the interest that the Court seeks to safeguard.

This is so even if the remedy is fully compensatory for an individual litigant. If the right or norm's value is lower than the cost of asserting the claim or if the remedy does little to advance the litigant's related interests, the rational litigant will not bother to assert that interest. ${ }^{162}$ For instance, much of the debate over the lawfulness of class-action waivers in consumer arbitration agreements centers on the problem of ensuring that consumers have incentive to assert a fully compensated right. ${ }^{163}$ An arbitration agreement may well provide full compensation for a breach-of-contract or tort claim in

87-88 (discussing the contributions of Amar and other scholars to the discussion of remedies).

158. See, e.g., Regents of Univ. of Cal. v. Bakke, 438 U.S. 265, 320 (1978) (Powell, J.) (directing admission of a Caucasian student to medical school); Christopher J. Peters, Assessing the New Judicial Minimalism, 100 COLUM. L. REV. 1454, 1515 n.254 (2000) (referring to Swann v. Charlotte-Mecklenburg Bd. of Educ., 402 U.S. 1, 31-32 (1971)).

159. See Daniel M. Filler, Silence and the Racial Dimension of Megan's Law, 89 IowA L. REV. 1535, 1589 (2004).

160. See Angela C. Zambrano, Robert Velevis \& Kent Barnett, Wavering Over Consumer Class Actions, 12 BANKING \& Fin. SERVs. POL'y REP., Dec. 2008, at 4, 6 (considering consumers' incentive to litigate low-value claims); $c f$. Ann C. McGinley \& Jeffrey W. Stempel, Condescending Contradictions: Richard Posner's Pragmatism \& Pregnancy Discrimination, 46 FLA. L. REV. 193, 254 n.443 (1994) (noting, in corrective justice terms, incentive problems in rendering low-value discrimination claims difficult to assert).

161. See Ryder v. United States, 515 U.S. 177, 183, 186 (1995).

162. See supra note 160 .

163. See, e.g., Scott v. Cingular Wireless, 161 P.3d 1000, 1006 (Wash. 2007) (en banc) (citing cases), abrogated on preemption grounds by AT\&T Mobility v. Concepcion, $131 \mathrm{~S}$. Ct. 1740 (2011), as recognized in Coneff v. AT\&T, 673 F.3d 1155 (9th Cir. 2012). 
arbitration proceedings. ${ }^{164}$ However, if full compensation is relatively small and less than the financial and opportunity costs of asserting the legal claim, the wronged party will likely not bother to assert the right. As Judge Posner has colorfully stated, "only a lunatic or a fanatic sues over $\$ 30 . ” 165$

The lack of incentive may be less obvious in the case of regulated corporate parties. Regulated parties, for example, often have incentives to litigate because they have better access to the judicial system than consumers, and, given their typically long-term relationship and repeat-player status with agencies, they stand to suffer or gain more from any particular judicial or administrative decision. ${ }^{166}$ But limited remedies and frequent interaction with agencies sometimes encourage timidity in challenging administrative structure. Public-choice theory as applied in the regulatory context, after all, suggests that regulated repeat players will not want to risk offending the same officials whose cooperation and favor they may need in the future. ${ }^{167}$ To be sure, many officials' professionalism or unawareness of the proceedings may prevent them from becoming hostile, and any particular official's response is usually a matter of speculation. But the uncertain reaction of any particular agency official will itself be a variable in the litigation calculus of regulated parties who interact frequently with a particular administrative agency. In fact, a regulated party who challenged the CFPB on separation-of-powers grounds expressed its fears that parties who challenge the CFPB's constitutionality face the threat of the CFPB bringing a retaliatory enforcement action. ${ }^{168}$ Moreover, other scholars

164. See id. at 1007.

165. Carnegie v. Household Int'l, Inc., 376 F.3d 656, 661 (7th Cir. 2004).

166. See John D. Echeverria \& Julie B. Kaplan, Poisonous Procedural "Reform": In Defense of Environmental Right-to-Know, 12 KAN. J.L. \& PUB. POL'Y 579, 608 (2003).

167. See Jody Freeman, The Private Role in Public Governance, 75 N.Y.U. L. REV. 543, 636 (2000); Richard B. Stewart, The Reformation of American Administrative Law, 88 HARV. L. REV. 1667, 1682-83 (1975). The meaning of "public choice theory" is notoriously "supple." Cynthia R. Farina, Faith, Hope, and Rationality or Public Choice and the Perils of Occam's Razor, 28 FLA. ST. U. L. REV. 109, 115 n.16 (2000). I use the term here merely to refer to an economic understanding of agency motivation, which often considers relationships among various actors, including the agencies themselves, in administrative and legislative decision-making. See KeITH WERHAN, PRINCIPLES OF ADMINISTRATIVE LAW 7 (2008).

168. See Morgan Drexen, Inc. v. CFPB, _ F. Supp. 2d _, _, 2013 WL 5664696, at *7 (D.D.C. Oct. 17, 2013). The CFPB had been investigating Morgan Drexen and advised that it was considering an enforcement action. Morgan Drexen then filed its constitutional challenge, and the CFPB in turn filed its enforcement action in another jurisdiction. See id. at $* 2-3$. The court found Morgan Drexen's fears "exaggerate[ed]," and it presumed that the CFPB's "enforcement actions are brought in good faith." Id. at *7. 
have noted a similar phenomenon in the context of judicial disqualification motions, where parties are hesitant to question an adjudicator's impartiality, even where a strong case for establishing a conflict of interest exists. ${ }^{169}$

Moreover, a regulated party's incentive to assert a structural challenge may be meaningfully different from a regulated party's incentive to assert a substantive, policy-based challenge under the APA. If, for example, a successful structural challenge results only in formal changes to the agency's design, the potential reward for a successful challenge is hard to define ex ante and perhaps not meaningful to the regulated party's substantive goals. This same successful challenge to the officials' very legitimacy may also lead to a risk of offending these officials and causing them, consciously or not, to be uncooperative in future regulatory matters with the litigant. The regulated party may find the risk-and-reward calculus more favorable with a traditional challenge to agency action under the APA. A successful challenge under the APA is more likely than a structural challenge to provide remedies that alter a substantive administrative action without offending agency officials. For APA challenges, the agency's and officials' legitimacy does not come into question-only the specific action does. For example, the candidates in Buckley could have challenged the FEC's specific election-finance rulings (assuming that they were otherwise suitable for judicial review), had orders or rules set aside under the APA as "arbitrary or capricious," and returned to any ongoing or future agency proceedings with a clearer understanding of the governing substantive law. ${ }^{170}$ These kinds of substantive challenges to agency action are routine under the APA and do not involve challenges to an agency's very legitimacy. The regulated party, therefore, has more incentive to bring the APA challenge.

Of course, substantive or procedural challenges to agency action will not always lead to a new result, ${ }^{171}$ but the odds are better than with a structural challenge. The agency may, upon remand, come to the same conclusion, although this time after a permissible process or

169. See, e.g., Michelle T. Friedland, Disqualification or Suppression: Due Process and the Response to Judicial Campaign Speech, 104 COLUM. L. REV. 563, 614 (2004); Tobin A. Sparling, Keeping Up Appearances: The Constitutionality of the Model Code of Judicial Conduct's Prohibition on Extrajudicial Speech Creating the Appearance of Bias, 19 GEO. J. LEGAL ETHICS 441, 479-80 (2006).

170. See 5 U.S.C. $\S 706(2)$ (A) (2012).

171. See Nate Hausman, Monsanto Co. v. Geerston Seed Farms: Breathing a Sigh of Equitable Relief, 25 TUL. ENVTL. L.J. 155, 188 (2011). 
upon a reasoned basis. ${ }^{172}$ But the judiciary's rejection of agency reasoning or procedures makes it more likely that an agency may adjust its policy, given that regulated parties likely obtain more control in the next round of administrative proceedings by obtaining more procedures (which provides time to organize any regulatory allies) or taking off the table certain arguments that the agency relied upon in past proceedings. A structural challenge, in contrast, may lead to new proceedings, but the agency-even if not offended by the structural challenge-does not need to use different reasoning or procedures to reach the prior result or continue its course of action. ${ }^{173}$ To be sure, political pressures may, at least theoretically, increase or decrease after the structural alteration to the agency, affecting the administrative action. ${ }^{174}$ Yet their existence or effect is difficult to determine in advance, and it may be that the regulated party cannot control them.

\section{Deterrence}

Remedies that compensate and incentivize the wronged party usually also deter violation of private- and public-law rights. ${ }^{175}$ Indeed, deterrence from such a remedy may be at its zenith when the damages are less certain and potentially very substantial. ${ }^{176}$ But

172. See SEC v. Chenery, 332 U.S. 194, 200-06 (1947).

173. See, e.g., Ryder v. United States, 515 U.S. 177, 188 (1995).

174. The political pressures could properly increase or decrease, depending on the nature of the structural change. Because the Appointments Clause is intended to hold an appointing official politically accountable usually to the President and perhaps the Senate, see Ryder, 515 U.S. at 182 (citing Freytag v. Comm'r, 501 U.S. 868, 878 (1991)), requiring new administrative action through a properly appointed official may increase the political nature of a particular agency decision. Likewise, an agency official who loses protections from removal may, at least theoretically, be subject to additional political persuasion by the President or other executive-branch officials. See supra text accompanying notes 4655. But political pressures could properly decrease if a court decides that an Article III court—whose judges have numerous protections from political influence-must decide a certain matter instead of an administrative agency. See Stern v. Marshall, 131 S. Ct. 2594, 2609 (2011). Or, similarly, political pressure could decrease if a court determines that an agency has implied statutory protection from the President's at-will removal. See Wiener v. United States, 357 U.S. 349, 353-54 (1958).

175. See Dellinger, supra note 34, at 1553; Gewirtz, supra note 34, at 592; Wright, supra note 33 , at 381 .

176. See Elizabeth D. De Armond, A Dearth of Remedies, 113 PENn ST. L. REV. 1, 49 (2008); Jason S. Johnston, Punitive Liability: A New Paradigm of Efficiency in Tort Law, 87 Colum. L. REV. 1385, 1405-06 (1987). But see Gregory Klass, Contracting for Cooperation in Recovery, 117 YALE L.J. 2, 22 (2007) (concluding, in the context of compensatory damages for breach of contractual terms meant to aid in any recovery, that "unliquidated compensatory damages for obstructive breach will, in many cases, do little or nothing to deter the promisor who would otherwise obstruct recovery"). 
remedies that compensate and incentivize will not (and perhaps should not, in certain contexts) always deter. For example, providing expectation damages may compensate a non-breaching party to a contract, and the damages-if sufficiently large-may provide sufficient incentive for that party to seek redress. Yet those significant damages, especially if liquidated and thus certain, may not deter the breaching party when the breach is economically efficient. ${ }^{177}$ Likewise, even tortfeasors may determine the efficiency of a breached duty, as Ford's infamous cost-benefit memo in the "Pinto Case" attests. ${ }^{178}$ Thus for the law to deter, it may need to provide other familiar remedies, such as punitive, ${ }^{179}$ scheduled, ${ }^{180}$ or treble damages. ${ }^{181}$ Non-pecuniary remedies might also be developed, such as

177. Of course, for adherents of efficient breach, breach is not an undesirable event. Instead, it is merely one of two permissible choices, based on economic benefits: (1) perform under the contract or (2) breach and pay damages to the other party while entering into another, more profitable contract. See William J. Woodward, Jr., Contractarians, Community, and the Tort of Interference with Contract, 80 MINN. L. REV. 1103, 1138 (1996). If the breach is not undesirable, then deterrence has no place. See Wright, supra note 33, at 379. But structural safeguards in the Constitution do not present a choice between two economic alternatives; instead, they are prophylactic rules that seek to prevent the gradual usurpation of one branch's power by another and to create the proper political incentives for governmental officers. See Plaut v. Spendthrift Farm, Inc., 514 U.S. 211, 239 (1995) (discussing separation of powers); supra Part I. The Constitution, in other words, has already established the undesirable nature of certain administrative schemes, rendering deterrence a potentially germane value for an appropriate remedy.

178. See David G. Owen, Problems in Assessing Punitive Damages Against Manufacturers of Defective Products, 49 U. CHI. L. REV. 1, 16-17 \& n.80 (1982). In the memo, Ford calculated that the cost of victim injuries and deaths from not using safer fuel tanks was less than the cost of modifying its cars to include safer fuel tanks. Id. As Professor Owen argues, the tortfeasor's utilitarian considerations laid the basis for punitive damages, the purpose of which was to punish Ford and deter similar future conduct. $I d$. at 20-28. Compensatory damages-even if uncertain and significant-did not deter Ford's action. Id.

179. This is not to say that these other remedies, including even punitive damages, necessarily accomplish the goal of deterrence. See DoBBS, supra note 117, at 220.

180. See Bray, supra note 104, at 756-57 (recognizing the deterrent effect of scheduled damages that are excessive).

181. See Tex. Indus., Inc. v. Radcliff Materials, Inc., 451 U.S. 630, 639 (1981) ("The very idea of treble damages reveals an intent to punish past, and to deter future, unlawful conduct...."); John R. Harrison, Jr., Comment, The Deceptive Trade PracticesConsumer Protection Act: The Shield Becomes the Sword, 17 ST. MARY's L.J. 879, 915 n.222 (1986). Treble damages can also serve as a means of providing incentive to litigants to seek redress. See G. Robert Blakey \& Thomas A. Perry, An Analysis of the Myths that Bolster Efforts to Rewrite RICO and the Various Proposals for Reform: "Mother of GodIs This the End of RICO?”, 43 VAND. L. REV. 851, 912-13 n.166 (1990) (considering RICO); Christina L. Goshaw, Note, Tomilson v. Camel City Motors, Inc.: The North Carolina Supreme Court's Hybrid Solution to Surety Liability Under General Statutes Section 75-16, 70 N.C. L. REV. 1959, 1977 (1992). 
the exclusionary rule for evidence obtained in violation of the Fourth Amendment. ${ }^{182}$

For structural-defect challenges, deterrence-based judicial remedies may be difficult to formulate. First, the sovereign-immunity doctrine limits the ability of courts to provide pecuniary remedies whether they are meant to compensate or deter. ${ }^{183}$ Indeed, Congress is even more unlikely to waive (and courts much less likely to find a waiver of) the government's sovereign immunity from punitive damages. ${ }^{184}$ Second, deterrence-driven non-pecuniary remedies may be unnecessarily destructive to the administrative state, causing harms not only to the government but also to regulated parties. For instance, invalidating an entire agency or organic act based on concerns about the excessive independence of agency officials could be detrimental by halting pending, meritorious investigations and beneficial regulatory policymaking. Invalidation could also cause chaos for regulated entities which are not parties to the litigation by leaving the validity of previously promulgated regulations, interpretive rules, and agency precedent up in the air. ${ }^{185}$ Given these concerns, it is not surprising that the Court has endeavored to salvage the agency's functions and granted Congress time to correct constitutional problems. ${ }^{186}$ Indeed, some have argued that, as a matter of separation-of-powers, the Court should seek to uphold congressional work product to the extent possible. ${ }^{187}$ Yet limiting administrative powers and confusion ensures that Congress (and usually the President) feels little pain when enacting legislation that

182. See Stone v. Powell, 428 U.S. 465, 486 (1976); Richard A. Posner, Excessive Sanctions for Governmental Misconduct in Criminal Cases, 57 WASH. L. REV. 635, 638 (1982).

183. See supra Part II.B.1.

184. See, e.g., 28 U.S.C. $\$ 2674$ (2012); U.S. Dep’t of Energy v. Ohio, 503 U.S. 607, 62728 (1992), superseded by statute as stated in Crowley Marine Servs. v. FEDNAV LTD., 915 F. Supp. 218, 222-23 (E.D. Wash. 1995).

185. Cf., e.g., Kaplinsky, supra note 30 ("Would any or all of the CFPB's actions since Mr. Cordray was appointed be invalid? How do you unscramble the egg? What about future CFPB actions?").

186. See Buckley v. Valeo, 424 U.S. 1, 137-43 (1976) (per curiam); see also Thomas E. Carlson, The Case for Bankruptcy Appellate Panels, 1990 B.Y.U. L. REV. 545, 571 n.121 (noting that the Supreme Court refused to give its holding in Northern Pipeline Construction Co. v. Marathon Pipe Line Co., 458 U.S. 50 (1982), retroactive effect). Similar practical considerations routinely influence judicial remedies. See DoBBS, supra note 117 , at $4-5$.

187. See, e.g., Bowsher v. Synar, 478 U.S. 714, 777-78 (1986) (Blackmun, J., dissenting) (advocating for invalidation of the "all but forgotten" removal provision instead of the "important federal enactments"); ALEXANDER M. BICKEL, THE LEAST DANGEROUS BRANCH: THE SUPREME COURT AT THE BAR OF POLITICS 111-98 (2d ed. 1986); Gorod, supra note 16, at 906, 918-19. 
violates the Constitution's structural safeguards. ${ }^{188}$ In other words, because the courts' remedies exact a low "price" per violation, the remedies lose deterrent effect. ${ }^{189}$

By considering a remedy's deterrent effect on Congress and the President, a key difference between structural challenges and most other administrative litigation becomes apparent. In run-of-the-mill challenges to agency action, the action at issue, whether investigatory, adjudicatory, or rulemaking, is the action of the agency itself. But with structural challenges, the action at issue-the propriety of the administrative establishment-concerns the action of Congress and the President, who together enacted legislation that created the agency. Congress and the President, however, are not before the courts in the structural-challenge litigation, at least not in any practical sense. ${ }^{190}$ Although the United States may be a named party in such an action, ${ }^{191}$ the litigation will almost certainly be handled by agency or other executive-branch lawyers. ${ }^{192}$ The President and

188. Indeed, the executive branch, despite its role in enacting a structural defect in most instances, may benefit in three ways when the courts craft an ineffective, pragmatic remedy. First, the courts' pragmatic concerns for administrative functioning can enable the executive branch to avoid administrative uncertainty and disruption that a structural defect might otherwise bring. Second, a structural defect often inures to the executive branch's benefit because the President has a role in all but one method of appointing officers under the Appointments Clause (and a concomitant removal power) and because the President, at least in theory, gains power when an agency officer loses protection from removal. Third, the executive branch may obtain political capital in Congress's and the public's eyes by originally agreeing to legislation that "diminish[es] [future presidents'] powers," Free Enter. Fund v. Pub. Co. Accounting Oversight Bd., 131 S. Ct. 3138, 3155 (2010), despite its later unconstitutionality.

189. See Levinson, supra note 32, at 889.

190. Remedies for unconstitutional legislation outside of the structural context may pose similar deterrence problems, but typical remedies for such violations (such as injunctions and invalidated orders) may prove to be more successful remedies overall. Although Congress and the President may enact unconstitutional, non-structural legislation, they almost certainly will not be parties to any future litigation. Instead, the agency officials will be the proper parties. Thus, deterrence may prove problematic. But the structural challenge is more perplexing because of the litigation-incentive issues discussed in Part II.B.2. A litigant who prevails in finding a substantive law unconstitutional obtains the invalidation or limitation of substantive or procedural agency action.

191. See 5 U.S.C. $§ 703$ (2012).

192. See Amanda Frost, Congress in Court, 59 UCLA L. REV. 914, 937-47 (2012). Professor Frost notes how rarely Congress has its own counsel in litigation, except in certain instances in which the executive and legislative branches have significant, conflicting interests. $I d$. Those instances included cases concerning the so-called legislative veto in INS v. Chadha, 462 U.S. 919 (1983), "the line-item veto, the independent counsel statute, and qui tam provisions of the False Claims Act." Id. at 945. Indeed, Congress has not appeared when the executive branch advocates a position that, at least in theory, reduces the President's power and enhances Congress's. See Free Enter. Fund v. Pub. Co. 
Congress are almost never parties and are also very unlikely to be involved even behind the scenes. ${ }^{193}$ Deterring violators who are absent from court presents a difficult judicial exercise.

Even assuming that deterrence could be achieved, it may be a misplaced value in most structural challenges. Although the Supreme Court's structural jurisprudence has become more analytically formal, it is often far from consistent or clear. It often fails to provide Congress notice of exactly which structures are verboten and thus limits intentional or even negligent structural violations. For instance, in the Appointments Clause context, Congress has, with one notable exception, ${ }^{194}$ generally failed to perceive correctly whether an officer was an inferior or principal officer or whether a particular officer was a "head of department." 195 Congress's failure is understandable because the Supreme Court has provided two principles for determining a government official's status-one based on an official's importance and the other based on her subordination to other officials - that may lead to two different results, ${ }^{196}$ and it has also altered descriptions of which administrative entities constitute "departments." 197 The Court itself has recently conceded that its

Accounting Oversight Bd., No. 08-861, Docket, SUPREME COURT OF THE UNITED STATES, http://www.supremecourt.gov/Search.aspx?FileName=/docketfiles/08-861.htm (last visited Dec. 28, 2013). Because the executive branch typically seeks to uphold the constitutionality of federal legislation, the executive branch's arguments may often advocate an expansive view of Congress's powers (perhaps at the President's expense), whether in structuring the administrative state or otherwise. See Free Enter. Fund, $130 \mathrm{~S}$. Ct. at 3166-70. Usually, litigation decisions are left to the Department of Justice, not any particular agency. See Kirti Datla \& Richard Ravesz, Deconstructing Independent Agencies (and Executive Agencies), 96 CORNELL L. REV. 769, 800-01 (2013).

193. Cf. Kagan, supra note 129, at 2273 ("[N]o President can hope (even with the assistance of close aides) to monitor the agencies so closely as to substitute all his preferences for those of the bureaucracy.").

194. See Buckley v. Valeo, 424 U.S. 1, 125 (1976) (per curiam). In Buckley, the legislation called for the blatantly unconstitutional appointment of six FEC commissioners. Despite the Appointment Clause's clear requirement that the President nominate and the Senate confirm principal officers, the legislation called for the entire Congress to confirm two commissioners nominated by the President, the President pro tempore of the Senate, and the Speaker of the House. See id. at 113; see also infra note 291 (describing how the constitutional issue concerning FEC's appointments was raised and ignored).

195. See, e.g., Ryder v. United States, 515 U.S. 177, 186-88 (1995).

196. See supra notes $42-45$ and accompanying text.

197. The Court's definition of "department" continues to expand its unclear contours and affects who is permitted to appoint inferior officers. See Barnett, Appointment with Trouble, supra note 38, at 1468-81. 
Article III jurisprudence has "not been entirely consistent." 198 And the undulation of the Court's formalistic and functional approaches to the President's removal power under Article II may excuse Congress from providing any particular decision much weight. ${ }^{199}$ Yet, to its credit, Congress has, at times, sought to comply with the Court's structural limiting principles once the Court has announced them. ${ }^{200}$ Considering the Court's unclear jurisprudence and Congress's general lack of apparent willfulness, little basis may exist for deterring Congress from failing to adhere to jurisprudence that has been labeled "incoherent,"201 "inconsistent,"202 and "ad hoc."203

\section{STRUCTURAL REMEDIES}

These remedial values can help to reveal the success or failure of specific structural-defect remedies. Below, I examine several structural remedies from the six most significant and recent judicial decisions in which the courts have held that a violation of the Appointments Clause, the President's removal powers, or Article III occurred. ${ }^{204}$ To ease the reader's comparison of similar remedies, I

198. Stern v. Marshall, 131 S. Ct. 2594, 2611 (2011); see also id. at 2621 (Scalia, J., concurring) (noting that the "multifactors relied upon today seem to have entered our jurisprudence almost randomly").

199. See Barnett, Independent Agency, supra 38, at 1356-58, 1367-69.

200. See Free Enter. Fund v. Pub. Co. Accounting Oversight Bd., 130 S. Ct. 3138, 3183 (Breyer, J., dissenting) (noting that during the nine-year period that the Court's jurisprudence suggested that Congress could not limit the President's power to remove executive officers, Congress did not protect officers from at-will removal).

201. See Rebecca L. Brown, Separated Powers and Ordered Liberty, 139 U. PA. L. REV. 1513, 1517 (1991).

202. See Erwin Chemerinsky, A Paradox Without Principle: A Comment on the Burger Court's Jurisprudence in Separation of Powers Cases, 60 S. CAL. L. REV. 1038, 1097 (1987).

203. See David M. Drisen, Toward a Duty-Based Theory of Executive Power, 78 FORDHAM L. REV. 71, 113 (2009). Although the value of punishment is similar to deterrence, it is not identical. See Catherine M. Sharkey, Punitive Damages as Societal Damages, 113 YALE L.J. 347, 363 (2003). Punishment seems even more inappropriate, given Congress's lack of intentional or willful structural violations. See DoBBS, supra note 117, at 204.

204. As noted, other less common separation-of-powers challenges are occasionally successful. See supra note 2. This Article limits itself to the more common Article III, appointments, and officer-removal challenges. Likewise, I have ignored challenges by federal officials for back pay because that remedy generally satisfies remedial values. See supra note 56. I also do not address Bowsher v. Synar in depth in this Section, see infra note 216 , because the statute at issue contained specific fallback provisions in anticipation of structural challenges and thus presents a different scenario than other cases. See Bowsher v. Synar, 478 U.S. 714, 718 (1986) ("Anticipating constitutional challenge to these procedures, the Act also contains a 'fallback' deficit reduction process to take effect '[i]n the event that any of the reporting procedures described in section 251 are invalidated.' "). 
have divided those decisions between (1) those whose remedies did not require a legislative or executive response to a structural violation because the Court cured the structural defect and (2) those whose remedies required congressional or executive action because the Court did not cure any, or all, of the structural defect. As illuminated below, this remedial feature often, but not always, distinguishes more successful structural remedies from less successful ones and suggests, as discussed later, a relatively straightforward way of improving structural remedies. ${ }^{205}$

\section{A. Severing the Structural Violation}

In three recent decisions, the courts' remedies did not require the legislature or the executive to respond and cure a structural defect. Instead, the courts either severed statutory provisions to cure structural defects for administrative agencies or otherwise limited the statutory reach of the bankruptcy courts' jurisdiction in an as-applied structural challenge to only those claims that could be heard in compliance with Article III. The remedy in two of these decisionsFree Enterprise Fund v. PCAOB and Intercollegiate Broadcasting Systems v. Copyright Royalty Board ${ }^{206}$ - largely, if not completely, failed to fulfill the remedial values discussed above (i.e., compensation, incentive to litigate, and deterrence) because Congress was not required to confront its constitutional violation and because the prevailing party was left in no better (or indeed perhaps a worse) position than it was before the challenge. But a similar remedy in Stern v. Marshall ${ }^{207}$ revealed that a minimalist remedy can be more, if not entirely, effective in satisfying key remedial values, at least in some jurisdiction-based challenges.

\section{Free Enterprise Fund}

As previously noted, Free Enterprise Fund concerned the PCAOB's investigation of the plaintiff accounting firm. ${ }^{208}$ The plaintiff, supported in the litigation by a nonprofit organization, argued that the board's significant independence from the SEC, which in turn was largely independent of the President, improperly

205. See infra Part IV.A.2.

206. 684 F.3d 1332, 1336 (D.C. Cir. 2012), cert. denied, 133 S. Ct. 2735 (U.S. May 28, 2013) (No. 12-928).

207. 131 S. Ct. 2594 (2011).

208. Free Enter. Fund v. Pub. Co. Accounting Oversight Bd., 130 S. Ct. 3138, 3149 (2010). 
impeded the President's supervisory powers under Article II. ${ }^{209}$ The Court agreed, holding that two tiers of "tenure protection" between the board and the President (one implied tier for the SEC and one express tier for the board) were too much. ${ }^{210}$ Instead of enjoining the board from taking any actions under SOX, as the plaintiffs had requested, the Court merely stripped the PCAOB members of their protection from removal from office by the SEC, thus rendering the board's members removable at will by the SEC. ${ }^{211}$ The Court then remanded the matter to the board, which retained all of its substantive powers. ${ }^{212}$

The Court's remedy failed to satisfy the first remedial value in that it provided no compensation for past harm and incomplete prospective enforcement of the safeguard. To be sure, the Court prevented some future harm by invalidating the limitations on removal. But, as with challenges to an agency's substantive powers, the regulated party was not compensated for the litigation and investigation costs (excluding the litigation costs from judicial proceedings) that occurred under the improperly structured board. The regulated party did not even obtain a new proceeding from the Court because the Court merely remanded the matter for continued review before a now-properly structured board comprised of the same personnel. ${ }^{213}$ The new proceedings thus picked up where the "tainted" proceedings left off, meaning that the remedy did not even ensure that the structural harms would be prevented going forward for the investigation of the accounting firm. Nor did the remedy correct harms that might continue to flow from the board's prior actions (whether those actions concerned related investigations, rulemaking, guidance documents, or other conduct), including those actions that came to bear directly on the plaintiff. ${ }^{214}$

209. Id.

210. See id. at 3151-61.

211. See id. at 3161.

212. Id. at 3161,3164 .

213. See id. at 3164; see also id. at 3161 (noting that SOX "remains fully operative as a law with these tenure restrictions excised" (internal quotation marks omitted)).

214. That said, the accounting firm was ultimately able to settle its litigation with the PCAOB with an agreement by which the agency would withdraw inspection reports but continue to have the option of investigating any past or future conduct. See Michael Cohn, Beckstead and Watts Settles Inspection Case with PCAOB, ACCT. TODAY (Feb. 23, 2011), http://www.accountingtoday.com/news/Beckstead-Watts-Settles-Inspection-Case-PCAOB $-57388-1 . h t m l$. The settlement arose as the accounting firm sought in federal district court to nullify the inspection report that was prepared under the auspices of the PCAOB as originally established. See id. 
Even if the Court's remedy provides prospective enforcement, it may not fulfill the second remedial value of providing incentive to assert future structural challenges. In Free Enterprise Fund, for example, even if the nonprofit organization that joined the regulated party's litigation paid all of the regulated party's legal costs, the regulated party was ultimately placed in an arguably worse position than it was before the challenge. The investigation continued with a potentially more hostile board, whose members can now be removed at will by the SEC. The regulated party's victory did nothing to alter the substantive landscape upon which the board can regulate, and it did not appear to open up a meaningful lobbying avenue for the regulated party to the SEC, which presumably has faith in the board's members it appoints. At most, the unsettled nature of the proper remedies may have allowed the accounting firm to have a more favorable settlement position with the agency in this particular case. ${ }^{215}$

The remedy also does not meaningfully deter Congress in the future. The Court could have chosen, as it did in Bowsher v. Synar, to invalidate the board's substantive powers ${ }^{216}$ as the plaintiffs requested. ${ }^{217} \mathrm{~A}$ remedy that limited substantive powers would likely have provided more litigation incentive to regulated parties because the board would lose meaningful powers over investigations and

215. See id. (noting that the accounting firm had sought additional remedies in the district court and also that the agency spokeswoman's explanation of the special circumstances of this dispute).

216. See Free Enter. Fund at 3162. In Bowsher v. Synar, 478 U.S. 714 (1986), the Court responded to a structural defect by invalidating the Comptroller General's executive powers, but leaving the Comptroller's tenure protection in place. See id. at 733-35. Such a remedy is certainly more advantageous from the regulated party's point of view. The affected party in Bowsher was a union for treasury employees who would be affected by the Comptroller General's budget cuts. See id. at 719. The Act, as written, required the President to accept the budget cuts that the Comptroller sought after reviewing reports by the Office of Management and Budget and the Congressional Budget Office. See id. at 717-18. The Court held that the Comptroller was improperly exercising executive power because the Congress, not the President, could remove him from office. See id. at 722-34. The Court relied upon Congress's statutory "fallback" provisions in its remedy; these provisions treated the Comptroller's report merely as a recommendation that required congressional and presidential approval to become effective. See id. at 734-36. Prior to the Court's decision, the union could meaningfully advance its argument before the Comptroller General alone or perhaps before the Office of Management and Budget and the Congressional Budget Office, both of which provided recommended cuts to the Comptroller General. After the Court's decision, the union could seek to advance its position through more diverse, and perhaps more accessible, levers of power: the Comptroller, the House, the Senate, and the President. The Court's remedy for a structural defect provided the impacted party with more avenues for altering the substantive decision and therefore more incentive to litigate.

217. See Brief for Petitioners at 62, Free Enter. Fund, 130 S. Ct. 3138 (No. 08-891), 2009 WL 2247130. 
enforcement directed at those very parties. Such a significant disruption of SOX's enforcement would also have been likely to cause Congress to take note of its constitutional misstep. Even if the Court had merely required Congress itself to decide how to restructure the agency to comport with the Court's decision, it would have caused Congress to bear the costs of legislating anew. When the Court solved the problem by disturbing the regulatory scheme as little as possible, it diluted incentives for future Congresses to consider structural concerns when drafting legislation. Thus, the Court's decision in Free Enterprise Fund generally failed to satisfy the three key remedial values.

To be sure, severing an unconstitutional portion of a statute may comport with understandable efforts to implement "fallback" congressional intent and limit disruption to federal programs. ${ }^{218}$ But severance in the structural context also undermines the three remedial values. Most importantly, in a case like Free Enterprise Fund, such a remedy (without more) provides the prevailing litigant no substantive benefit. Severance, in short, may create a superficial appearance that the Court carefully responded to the precise constitutional violation it identified. Yet a remedy that offers no advantages at all to the remedy-seeking plaintiff is not likely to foster remediation of similar structural wrongs in the future.

\section{Intercollegiate Broadcasting System}

A recent ruling from the D.C. Circuit further demonstrates the problems that arise when courts apply the ineffective remedy from Free Enterprise Fund to other structural challenges. In Intercollegiate Broadcasting System, Inc. v. Copyright Royalty Board, the D.C. Circuit held that Copyright Royalty Judges ("CRJs") were not properly appointed by the Librarian of Congress because they were principal, as opposed to inferior, officers. ${ }^{219}$ Principal officers, unlike inferior officers, must be nominated by the President and confirmed by the Senate. ${ }^{220}$ According to the court, CRJs were principal officers because of their substantive ratemaking powers and their protection from removal from office by the Librarian of Congress. ${ }^{221}$ The remedy the plaintiff sought in the case is not clear, but the plaintiff appears to

218. See Free Enter. Fund, 130 S. Ct. at 3161 (quoting Ayotte v. Planned Parenthood of N. New Eng., 546 U.S. 320, 328-29 (2006)).

219. See Intercollegiate Broad. Sys., Inc. v. Copyright Royalty Bd., 684 F.3d 1332, 1336

(D.C. Cir. 2012), cert. denied, 133 S. Ct. 2735 (U.S. May 28, 2013) (No. 12-928).

220. See U.S. CONST. art. II, § 2 cl. 2.

221. See Intercollegiate Broad. Sys., Inc., 684 F.3d at 1336. 
have wanted the court to invalidate the underlying ratemaking decision based on the structural defect or, if it's structural challenge was not successful, to remand the matter to the Copyright Royalty Board with certain instructions on how to assess proper rates. ${ }^{222}$ The D.C. Circuit, however, decided to remedy the violation "with as little disruption as possible" 223 by providing the same remedy as the Supreme Court provided in Free Enterprise Fund. ${ }^{224}$ The D.C. Circuit invalidated the limitations on the Librarian of Congress's power to remove the $\mathrm{CRJs},{ }^{225}$ thereby rendering them inferior officers, and remanded the matter for a new determination by those same judges. ${ }^{226}$ As described below, this remedy was ineffective, failing to achieve two of the three remedial purposes that underpin the law of remedies-litigation incentive and deterrence.

Regarding the first remedial value, the remedy in Intercollegiate Broadcasting System compensated Intercollegiate in a roundabout way. These judges were improperly appointed as principal officers by a department head. The D.C. Circuit later demoted them to inferior officers, but they were never appointed as inferior officers. Yet, despite this failing, the protection from removal that the judges had when the Librarian of Congress appointed them may have benefited Intercollegiate. The judges' independence would likely have led the Librarian to be even more careful with the appointments because of the Librarian's more limited ability to control the judges. The Librarian was clearly identifiable as the appointing party and responsible for the choice. In short, although the original appointment was unconstitutional, the appointment exceeded the underlying principles that the Appointments Clause intends to further-creating political accountability in an identifiable individual for inferior-officer appointments. ${ }^{227}$ Moreover, the court remanded for a new determination, not merely continued proceedings, and thereby provided Intercollegiate with the structural rights that it was entitled to receive in the first instance. ${ }^{228}$

But, as in Free Enterprise Fund, the remedy fails to provide incentive to seek redress for future litigants. By invalidating the

222. See Opening Brief of Appellant at 18, Intercollegiate Broad. Sys., Inc., 684 F.3d 1332 (No. 11-1083), 2011 WL 3918320.

223. Intercollegiate Broad. Sys., Inc., 684 F.3d at 1336.

224. See id. at 1334.

225. See id. at 1342.

226. See id.

227. See supra text accompanying note 49.

228. See Intercollegiate Broad. Sys., Inc., 684 F.3d at 1342. 
statutory protections from at-will removal and remanding the matter to the very CRJs who can now be removed at will, the D.C. Circuit sent the prevailing litigant to potentially hostile judges. The extent to which the judges are actually hostile may be unknowable, even to them. But if the court's remedy applies in similar contexts, the specter of hostility that looms over follow-up proceedings would likely give most regulated parties pause before asserting structural challenges. ${ }^{229}$ After all, Intercollegiate received no other relief: no damages, no attorneys' fees, and, despite its request, no substantive instructions for the judges on remand. ${ }^{230}$ Nothing prevents the Copyright Royalty Board from imposing the same rates as it imposed in the original proceeding, and it could even do so without altering any of its reasoning or conclusions. Moreover, Intercollegiate will then face the prospect of taking yet another appeal-with its costs and attorneys' fees-to have the D.C. Circuit address the substance of its claims. Although the President and the Librarian of Congress gained power (whether real or theoretical) from the decision, Intercollegiate has gained little, if anything, from the challenge.

The D.C. Circuit's remedy also fails to deter Congress from creating other unconstitutional appointments in the first instance. Here, Congress permitted a department head to appoint principal officers. But Congress encounters no meaningful repercussions because of its constitutional violation. Congress has no need to take any action to avoid costs to the administrative state or to pay damages. Instead, the D.C. Circuit altered the statutory scheme to create, in its words, "as little disruption as possible." 231 Should other courts take similar action, future Congresses would have little incentive to ensure structural safeguards, including those under the Appointments Clause, when the courts will correct a problem of Congress's making.

The D.C. Circuit also did little to reinforce respect for the Appointments Clause while unnecessarily denigrating another constitutional safeguard. Instead of requiring Congress to confront the appointments issue with new legislation, the D.C. Circuit's focus on limited disruption of the statutory scheme led it to concentrate on a different structural safeguard-the executive branch's ability to supervise subordinate officers. While severing the protections from

229. Cf. Friedland, supra note 169, at 614 (discussing the hesitancy of parties to question adjudicators' impartiality, despite grounds to do so); Sparling, supra note 169, at 479-80.

230. See Intercollegiate Broad. Sys., Inc., 684 F.3d at 1341-42.

231. See id. at 1337. 
removal rendered the CRJs inferior for purposes of the Appointments Clause, it simultaneously invalidated these otherwise constitutional protections from removal.

Although the Supreme Court struck down one of the two layers of tenure protections in Free Enterprise Fund, ${ }^{232}$ it did not do so based on an Appointments Clause violation. ${ }^{233}$ Instead, its remedy related to Congress's provision of too much independence to PCAOB by cocooning PCAOB within two layers of protection from removal, so that the removal-related remedy directly targeted the structural defect. ${ }^{234}$ But in the case of the CRJs, they had only one tier of tenure protection (because the President can remove the Librarian of Congress at will) ${ }^{235}$ and thus a constitutional form of independence. ${ }^{236}$ Free Enterprise Fund, therefore, did not require its remedy here, and by relying on that decision, the D.C. Circuit hobbled the CRJs' independence despite the constitutionality of that independence.

By applying an ill-fitting remedy, the D.C. Circuit also created new problems. CRJs are now subject to political pressure when deciding matters because of their ability to be removed at will by the Librarian of Congress, whom the President, in turn, can remove at will. Despite decades of criticism concerning the unfairness of copyright-royalty proceedings ${ }^{237}$ the D.C. Circuit's remedy brings the fairness of those proceedings into question because political actors

232. See Free Enter. Fund v. Pub. Co. Accounting Oversight Bd., 130 S. Ct. 3138, 3161 (2010).

233. See id. at 3162. The Supreme Court relied on its invalidation of the tiered tenure protection when holding that the PCAOB members were inferior officers. See id. But the Court never determined whether the PCAOB members were principal officers during the time that they had tiered protections from removal. See id. Whether the invalidation remedy was designed as a way of limiting the disruptive effects that would arise had the Court found an Appointments Clause violation may have to await a perusal of the Justices' papers in the future.

234. See id. at 3161.

235. See Intercollegiate Broad. Sys., Inc., 684 F.3d at 1341.

236. See Free Enter. Fund, 130 S. Ct. at 3162; Morrison v. Olson, 487 U.S. 654, 692-93 (1988); accord Perkins v. United States, 116 U.S. 483, 484-85 (1886) ("[W]hen Congress, by law, vests the appointment of interior officers in the heads of Departments it may limit and restrict the power of removal as it deems best for the public interest. The constitutional authority in Congress to thus vest the appointment implies authority to limit, restrict, and regulate the removal by such laws as Congress may enact in relation to the officers so appointed. The head of a Department has no constitutional prerogative of appointment to offices independently of the legislation of Congress, and by such legislation he must be governed, not only in making appointments but in all that is incident thereto.").

237. See Craig Joyce et Al., Copyright Law 449-50 (8th ed. 2010). 
can assert more control over the hearings' outcomes. ${ }^{238}$ To be sure, the increased political nature of the proceedings may not raise due process concerns because the CRJs preside over ratemaking, ${ }^{239}$ not adjudicatory, hearings. ${ }^{240}$ But the D.C. Circuit should have at least considered its chosen remedy's effect on the fairness of those proceedings that Congress has long sought to improve. ${ }^{241}$

\section{Stern}

Unlike in Free Enterprise Fund and Intercollegiate Broadcasting System, a minimalist remedy in Stern v. Marshall (although one that did not require the severance of any statutory language) was more effective in satisfying key remedial values. ${ }^{242}$ The Stern Court, as the prevailing party requested, invalidated a bankruptcy court's order that resolved a state-law claim in the debtor's favor. ${ }^{243}$ The Court did so because the bankruptcy court's statutory jurisdiction over the state-law claim as part of the court's "core" bankruptcy jurisdiction violated Article III. ${ }^{244}$ By invalidating the bankruptcy court's order,

238. Drew Singer, Ruling could compromise U.S. administrative judges' autonomy, THOMSON REUTERS NEWS \& INSIGHT (Aug. 16, 2012, 5:38 PM), http://mobile.reuters.com/article/domesticNews/idUSBRE87F1AZ20120816.

239. See 5 U.S.C. § 551(4) (2012); Andrew D. Stephenson, Webcaster II: A Case Study of Business Rate Setting by Formal Rulemaking, 7 HASTINGS BUS. L.J. 393, 405 (2011).

240. See Bi-Metallic Inv. Co. v. State Bd. of Equalization, 239 U.S. 441, 445-46 (1915) (distinguishing Londoner v. Denver, 210 U.S. 373 (1908)).

241. Moreover, if courts applied the same remedy to other similarly situated officials, such as administrative law judges ("ALJs"), the remedy could create due process concerns. Unlike the CRJs' ratemaking proceedings, ALJs preside over adjudicatory proceedings for which the Due Process Clause requires sufficiently impartial adjudicators. See Londoner v. Denver, 210 U.S. 373, 385-86 (1908). To provide ALJs independence to further their impartiality, Congress has granted them protection from at-will removal. See 5 U.S.C. $\S 7521$ (a) (2012). ALJs' status as employees or officers is unresolved. See, e.g., Kent Barnett, Resolving the ALJ Quandary, 66 VAND. L. REV. 797, 809-14 (2013) (discussing questions concerning the propriety of ALJ appointments). If they are officers, many are not appointed properly because they are appointed by heads of agencies, not heads of departments. See $\S 3105$. A remedy that would seek to "demote" them from officers to employees by permitting at-will removal-as in Intercollegiate Broadcasting System - would raise significant questions as to the ALJs' impartiality and thus create (or inflame already existing) due process concerns. See Barnett, supra, at 816-28.

242. Although bankruptcy courts are not agencies, courts and scholars have long considered decisions concerning both agencies and Article I courts when deciding Article III issues. See, e.g., Stern v. Marshall, 131 S. Ct. 2594, 2613 (2011); CFTC v. Schor, 478 U.S. 833, 852 (1986); JOHN M. ROGERS, MichaEL HEALY \& RONALD J. KROTOSZYNSKI, JR., ADMINISTRATIVE LAW 312-46 (3d ed. 2012). I consider the bankruptcy decisions here because, despite the differences between structural challenges to Article I courts and agencies, the structural remedies in those cases can inform structural remedies in the administrative context.

243. See Stern, 131 S. Ct. at 2600-01.

244. See id. at 2608. 
the Court gave a later-in-time state-court judgment that favored the prevailing private party (i.e., the creditor) preclusive effect over the earlier bankruptcy-court judgment. ${ }^{245}$

Because the prevailing party obtained exactly what he had requested, the Court's remedy appears to have been sufficient for him to challenge the bankruptcy court's structure. Familiar and routine challenges to state and federal court jurisdiction suggest that remedies that provide either preclusive effect to a particular judgment or proceedings in a new forum create sufficient litigation incentive. This is so because the parties would then be left to litigate the issue in what the prevailing party perceives as a more favorable forum, whether because of a prevailing judgment or the beneficial reputation of the judge or juries. Indeed, the general availability of a new forum is what creates more incentive than may exist with other structural challenges, such as in Intercollegiate Broadcasting System, where the prevailing party must return to the authority of the challenged officials. ${ }^{246}$ Aside from generally non-compensable litigation costs, the prevailing party that receives a new forum would also obtain all to which it was originally entitled and thus be generally compensated for the structural violation.

The remedy also provided as much deterrence to Congress as exists for other substantive constitutional violations, even if that deterrence is rather insignificant. In Stern, the Court held that the particular kind of state-law claim was not properly before the bankruptcy court despite its statutory jurisdiction. ${ }^{247}$ The Court in essence established, as in other as-applied constitutional challenges, the constitutional limitations of the statutory grant of jurisdiction over "core" bankruptcy proceedings without severing any statutory language. Congress, as with most other applied challenges, likely feels little sting from the Court's limits on the bankruptcy court's jurisdiction. Thus, the remedy does little to deter Congress from violating Article III. Yet, this failure applies to many as-applied challenges, not only structural litigation. Moreover, given the Court's admission in Stern that its Article III jurisprudence "has not been entirely consistent," 248 it may be largely impossible to deter Congress from stepping over boundaries that it cannot ascertain. Thus, a remedy that involves merely severance may be slightly more

245. See id. at 2600-01.

246. See Intercollegiate Broad. Sys., Inc. v. Copyright Royalty Bd., 684 F.3d 1332, 1341-42 (D.C. Cir. 2012), cert. denied, 133 S. Ct. 2735 (U.S. May 28, 2013) (No. 12-928).

247. See Stern, 131 S. Ct. at 2600-01.

248. Id. at 2611. 
successful, although not entirely so, in satisfying remedial values as part of a jurisdiction-based challenge concerning only private-party litigants than in the purely regulatory context.

\section{B. Requiring Legislative or Executive Action}

Structural remedies better satisfy remedial values for prevailing parties when courts require the political branches to respond to the structural violation with curative action. Such was the case in Ryder $v$. United States. ${ }^{249}$ But courts have often dulled the remedy's effectiveness-for example in Buckley v. Valeo and, to a limited extent, Northern Pipeline Construction Co. v. Marathon Pipe Line Co. ${ }^{250}$-by validating past administrative actions and providing Congress lengthy stays of the judgment to fashion remedial legislation. By doing so, the courts have undermined the remedial values that are important to prevailing regulated parties.

\section{Ryder}

In Ryder, the Supreme Court determined that civilian judges of the Coast Guard Court of Military Review were not properly appointed and thus were unauthorized to hear Ryder's appeal for several drug-related convictions. ${ }^{251}$ The judges were inferior officers who were improperly appointed by the Department of Transportation's General Counsel, not the Secretary of Transportation-a department head-as the Appointments Clause and governing statute required. ${ }^{252}$ Turning to the remedial questions, the Court unanimously held that Ryder was "entitled to a hearing before a properly appointed panel of that court." 253 In reaching its conclusion, the Court rejected the "de facto officer doctrine," which validates the actions of those acting under the color of official title despite an invalid appointment. ${ }^{254}$ The Court noted that the doctrine was limited to mere statutory, as opposed to constitutional, challenges brought only on collateral review. ${ }^{255}$ The Court also recognized that it had created a similar de facto doctrine-distinct from the de facto

249. 515 U.S. 177 (1995).

250. 458 U.S. 50 (1982).

251. See Ryder, 515 U.S. at 179.

252. See id. at 179-80. The government conceded that the appointments violated the Appointments Clause. See Edmond v. United States, 520 U.S. 651, 655 (1997) (referring to Brief for the United States at 9 n.9, Ryder, 515 U.S. 177 (No. 94-431). 1995 WL 130573).

253. Ryder, 515 U.S. at 188.

254. See id. at 180.

255. See id. at 180-83. 
officer doctrine-for constitutional, appointments-based challenges. ${ }^{256}$ But the Court stated that it was "not inclined to extend" this other vague de facto doctrine beyond challenges to entire administrative or legislative bodies that implicated federal voting rights or elections. ${ }^{257}$

For the most part, the Ryder Court's remedy merits praise. The Court partially compensated Ryder and provided prospective enforcement of the safeguard by granting him a new hearing "before a properly appointed panel of that court." 258 This remedy, similar to specific performance in contract law, gave Ryder what he was entitled to receive in the first instance. In particular, the properly constituted panel might be different from the initial, improperly appointed panel; in this case, the rehearing would not be an empty gesture. ${ }^{259}$ And even if the same individuals were later appointed, their installation as adjudicators would have then undergone the political scrutiny that the Constitution requires. With the department head's new appointments, the appointment power would be properly cabined in limited executive officers, thereby requiring identifiable executive officers to take the praise and blame for the appointment. ${ }^{260}$ To be sure, the remedy did not fully compensate the prevailing litigant because he did not receive any compensation for the past harm, whether dignitary or financial, in having to participate in unconstitutional proceedings. But this remedial failing is common in public-law litigation. ${ }^{261}$

A new hearing before properly appointed officers likely provides as much litigation incentive as exists for other administrative-action challenges, even if the incentive is still relatively low. For instance, in the case of the Coast Guard judges, Congress had permitted the head of department-the Secretary of Transportation-to make the appointment, but he had failed to do so. ${ }^{262}$ The Secretary's appointment of these officers after the Court's decision took only a

256. See id. at $183-84$.

257. See id. The two decisions at issue included Buckley v. Valeo, 424 U.S. 1 (1976) (per curiam), which concerned the unconstitutional appointment of the FEC, and Connor v. Williams, 404 U.S. 549 (1972), in which the Court refused to invalidate the actions of legislators who were elected under an unconstitutional apportionment plan. See Ryder, 515 U.S. at $183-84$.

258. See Ryder, 515 U.S. at 188.

259. The likelihood of new individuals being appointed is probably very low. For instance, the Secretary of Transportation appointed the same civilian judges whose appointments were held invalid. See Edmond v. United States, 520 U.S. 651, 654 (1997).

260. See supra text accompanying note 49.

261. See supra Part II.B.1.

262. See Edmond, 520 U.S. at 656-58. 
minimal amount of administrative effort. ${ }^{263}$ Congress had authorized the appointment in a constitutional manner. The remedy-a hearing before properly appointed judges ${ }^{264}$ - cures the concerns that arose from the improper enforcement of Congress's legislation at little cost and tracks the remedy afforded for more common procedural violations. ${ }^{265}$ The challenger thus has as much incentive to challenge the structural defect as he or she would for challenging any other procedural administrative violation. Moreover, unlike with certain violations and remedies, the adjudicator, if later appointed (as is usual), arises from the challenge in a stronger position because the adjudicator is now unquestionably a properly appointed federal officer. This improved status should reduce a regulated party's real or speculative fears of animus. ${ }^{266}$ This minimal level of incentive is not optimal, but at least it corresponds to incentive for procedural challenges and, if the appointment is cured of its defect, provides more incentive than exists for other structural challenges by ultimately elevating the status of the challenged officers.

The remedy also has no need to deter Congress because Congress did not create an improper appointment. At the same time, the executive branch had to absorb the inefficiencies that redundant proceedings and a later proper appointment brought about, much as it must do after other successful administrative challenges. The remedy here of re-appointment may appear relatively minor, but it might be said so, too, is the transgression. Here, the wrong official within the department appointed the judges. The remedy's symmetry with harm requires the executive to assume some costs for the violation, even if those costs are not onerous. Ultimately, the remedy was mostly successful in satisfying the three key remedial values.

263. See, e.g., id. at 654 .

264. Of course, the prevailing party is not necessarily entitled to a different result. For example, the properly appointed military appellate tribunal once more rejected the same arguments that Ryder had presented in his original appellate hearing and once more affirmed his sentence. See United States v. Ryder, No. 947, at 2-3 (C.G. Ct. Crim. App. Apr. 23, 1997) (per curiam).

265. See, e.g., Chaffin, supra note 131, at 464-65 ("Most courts sustaining [procedural challenges based on section 553 of the APA] immediately invalidate the rule and remand the case to the agency with instructions to follow proper section 553 procedures.").

266. Yet, notice that when Congress has not provided the department head with statutory authority to appoint, the new hearing must await new legislation that grants the department head appointing authority. A department head may approbate the appointment of a subordinate only when a statute allows approbation. See United States v. Mouat, 124 U.S. 303, 308 (1888). In these cases, the incentive for challenging the action would increase because Congress may not enact curing legislation within the applicable limitations period or swiftly enough for the agency to maintain its interest in the regulated party or a particular regulatory action. 


\section{Buckley}

In contrast to the generally successful remedy in Ryder, the Court's structural remedy in Buckley v. Valeo demonstrates that merely requiring one or more political branches to take curative action does not by itself guarantee the satisfaction of key remedial values. In Buckley, political parties and candidates challenged provisions of the Federal Election Campaign Act of 1971, as amended in $1974 .{ }^{267}$ The plaintiffs successfully argued that, among other things, none of the commissioners of the FEC were properly installed under the Appointments Clause. ${ }^{268}$ As a remedy, the Court invalidated the FEC's executive powers (rulemaking, enforcement, and so forth) ${ }^{269}$ but allowed the FEC to continue its quasi-legislative functions (data collection). ${ }^{270}$ The Court also stayed its judgment for thirty days to permit Congress to reconstitute the FEC. ${ }^{271}$ Moreover, without any briefing from the parties on the proper remedy, ${ }^{272}$ the Court granted the FEC's past acts "de facto validity" ${ }^{273}$ and permitted the FEC to continue its executive functions during the period of the stay. ${ }^{274}$ The Buckley Court's remedy succeeded in satisfying the three remedial desiderata only in part, and it also raised troubling implications.

As to the first key remedial value, the Court's remedy provided no compensation whatsoever to the prevailing parties, except in the form of limited prospective relief. Even in the face of a blatant constitutional structural defect, the Court provided all of the FEC's past actions de facto validity, and because those past actions were deemed valid, the prevailing parties received no compensation for any harm the defect brought about. ${ }^{275}$ The Court later in Ryder stated

\footnotetext{
267. See Buckley v. Valeo, 424 U.S. 1, 7 (1976) (per curiam).

268. See id. at 9-11, 113 .

269. See id. at $138-41$.

270. See id. at $137-38$.

271. See id. at 143 .

272. See Conference Memorandum from Justice Rehnquist re: Buckley v. Valeo (Jan. 20,1976 ) ("I do not think that it would be wise for the Court to make a make a holding [as to the proper remedy] without the benefit of any argument or briefing."). It appears that the Court's remedy originated from Justice Brennan's chambers and that four Justices agreed during a luncheon. See Conference Memorandum from Justice Brennan re: Buckley v. Valeo (Jan. 20, 1976); Conference Memorandum from Justice Marshall re: Buckley v. Valeo (Jan. 20, 1976). All conference memos are available in Justice Powell's papers, held at the library at Washington and Lee University School of Law. See Powell Papers, WASH. \& LEE UNIV., http://law.wlu.edu/powellarchives/page.asp?pageid=236 (last visited Dec. 28, 2013).

273. Buckley, 424 U.S. at 142.

274. See id. at 143.

275. See Ryder v. United States, 515 U.S. 177, 182-83, 188 (1995); Stacy M. Lindstedt, Developing the Duffy Defect: Identifying Which Government Workers Are Constitutionally
} 
that the prevailing parties received the declaratory and injunctive relief that they had pursued. ${ }^{276}$ But the Buckley plaintiffs did not obtain all that they sought. They also requested complete invalidation of the FEC and its past actions. ${ }^{277}$ True, the regulated parties, without further action by Congress, would not have to worry about future FEC regulatory actions. But the Court's awarded relief afforded no compensation for past harms or full enforcement of the safeguard going forward because past agency actions remained in place. The Appointments Clause, the bastion of separation of powers, apparently has low walls and shallow moats.

The remedy provided, as to the second key remedial value, only limited incentive for future structural challenges. The constriction of the agency's prospective powers provided some incentive because if Congress failed to act within thirty days, the prevailing parties would have hobbled the FEC by having its significant enforcement and rulemaking powers invalidated. ${ }^{278}$ Nevertheless, the prevailing party continued to be subject to the agency's previous actions because of their de facto validity, thus dulling the regulated party's victory.

The Court's remedy likewise created only a limited deterrent effect and thereby did not fully satisfy the third key remedial value. The Court required Congress to reconstitute the FEC in a constitutional manner. ${ }^{279}$ If it failed to do so, the FEC would lose all executive power going forward. ${ }^{280}$ But the Court's stay, while respecting interbranch comity, ${ }^{281}$ limited the deterrent effect of its remedy because it gave Congress a chance to mend its ways without suffering any harm for the structural violation. ${ }^{282}$ Indeed, unlike the scenarios in which executive officials have failed to execute Congress's properly established appointments, ${ }^{283}$ the Court invalidated no agency order or action whatsoever. As long as Congress acted within thirty days, it was to be as if Congress never violated the Constitution at all. A structural-redesign grace period

Required to Be Appointed, 76 Mo. L. REV. 1143, 1185 (2011) (“[Buckley's] remedy, then, did not help anyone who may have been injured by the improper appointment ... up to that point.").

276. See Ryder, 515 U.S. at 183.

277. See Reply Brief of Appellants, Buckley, 424 U.S. 1 (Nos. 75-436, 75-437), 1975 WL 171458 , at $* 111$.

278. Buckley, 424 U.S. at 142-43.

279. See id.

280. See id. at $136-43$.

281. See Nagel, supra note 34 , at 718 .

282. See Buckley, 424 U.S. at 142-43.

283. See supra Part III.B.1. 
implicitly tells Congress that it may blatantly violate the Constitution's structural safeguards (or at least push structural boundaries to the maximum) and then later create a proper agency, if it acts fast enough, without any adverse consequences at all.

Much of the remedial inadequacy in Buckley comes from its improper validation of the agency's actions. As the Supreme Court later suggested in Ryder, the Buckley Court's reliance on a de facto validity doctrine-similar to, but apparently distinct from, the de facto officer doctrine-was misplaced. ${ }^{284}$ The de facto officer doctrine validates the actions of "a person acting under color of official title" despite a statutory defect concerning an officer's appointment in a collateral attack on a prior judgment. ${ }^{285}$ The purpose of the doctrine is to prevent, based on "technical defects," 286 chaos to the administrative state and uncertainty for parties that have relied on the individual's rulings. ${ }^{287}$ But the defect in Buckley was constitutional, not technical or statutory, and concerned the formation of a new independent agency. The Court provided no evidence of chaos that would arise without the validation of prior actions. Indeed, the agency was relatively new and had yet to engage in significant regulatory activity (outside of issuing numerous advisory opinions ${ }^{288}$ ) despite upcoming federal elections. ${ }^{289}$ Buckley, in other words, was not a suitable candidate for application of a de facto validity doctrine based on either the kind of structural defect at issue or its hypothesized ill effects.

The Ryder Court, however, twice suggested that a de facto validity doctrine-as opposed to the de facto officer doctrine-may apply when the structural challenge extends to an entire body where

284. See Ryder v. United States, 515 U.S. 177, 184 (1995).

285. See id. at 180; see also Clokey, supra note 51, at 1122 (citing EEOC v. Sears, Roebuck \& Co., 650 F.2d 14 (2d Cir. 1981); EEOC v. Sears, Roebuck \& Co., 504 F. Supp. 241 (N.D. Ill. 1980)) (noting rejected challenges to the expired term of an EEOC administrator).

286. Ryder, 515 U.S. at 180 (quoting 36A AM. JUR. 2D Public Officers and Employees $\S 578(1984))$.

287. See Albert Constantineau, A Treatise on the De Facto Doctrine 4 (1910); Gary Lawson \& Guy Seidman, The Hobbesian Constitution: Governing Without Authority, 95 Nw. U. L. REV. 581, 595, 600 (2001).

288. For a collection of the FEC's advisory opinions in 1975 alone, see Advisory Opinions, FED. ELECTION COMMISSION, http://saos.nictusa.com/saos/searchao;jsessionid $=$ C6860AFE8044A01A86808798736E97AE; jsessionid =9F6EAB2EE530E6E9AA17C2937 948D86F?SUBMIT=year \&YEAR=1975 (last visited Dec. 28, 2013).

289. See Buckley v. Valeo, 387 F. Supp. 135, 138 (D.D.C. 1975) (noting that the amendments became effective in October 1974 and issuing an opinion to the constitutional challenge in January 1975). 
"grave disruption or inequity" would arise. ${ }^{290}$ Although applying the doctrine in such situations may honor settled legal interests that occurred prior to the litigation, it creates a perverse relationship between the remedy and the significance of the violation: the more striking (and often obvious) the structural defect and its effects, the more insignificant the judicial remedy. To be sure, much harm can arise from the invalid appointment of those who head an agency. But for that reason, Congress, contrary to its actions in Buckley, should be attentive to the required (and relatively clear) strictures for a proper appointment. ${ }^{291}$ Even with the appointment of lower-level officers, the invalid appointment may be obvious, and the harm from improper appointments can be significant. ${ }^{292}$ An inverse remedy-toharm paradigm, in other words, actively seeks not to compensate and enforce, to provide incentive, or to deter based on perceived chaoschaos that arises directly from Congress's inattention to structural safeguards. The safeguards, contrary to the Court's panegyrics to their importance, look like technicalities and merely matters of etiquette and protocol that do not warrant full prospective enforcement.

This is not to say that a court's consideration of administrative chaos should be irrelevant in determining an equitable remedy. ${ }^{293}$ For instance, the disruption to the administrative state may be especially high in the context of already-final adjudications because the need to preserve settled legal interests is great. Of particular significance, the retroactive invalidation of final orders concerning parties who did not assert a structural challenge would provide no compensation or incentive to the prevailing party in the structural litigation. Any additional deterrent effect or judicial respect for the safeguard that

290. See Ryder, 515 U.S. at 183-85.

291. After all, Congress acknowledged and ignored the arguments that the appointments were blatantly unconstitutional. See, e.g., H.R. REP. NO. 93-1239, at 137-38 (1974); Various Measures Relating to Federal Election Reform: Hearings Before the Subcommittee on Privileges and Elections and the Committee on Rules and Administration on S. 23, S. 343, S. 372, S. 1094, S. 1189, S. 1303, S. 1355 \& S.J. Res. 110, 93d Cong. 352-54 (GAO memorandum); Hearings Before the Subcommittee on Elections of the Committee on House Administration on H.R. 7612, S. 372, and Related Election Reform Bills, 93d Cong. 141, 161, 192, 229 (discussing the functional necessity of cross-branch appointments).

292. See 35 U.S.C. $\S 6$ (2006 \& Supp. 2011) (providing constitutional appointments of Administrative Patent Judges ("APJs")); John F. Duffy, Are Administrative Patent Judges Unconstitutional?, 77 GEO. WASH. L. REV. 904, 915 (2009) (noting that the Director of the Patent and Trademark Office's appointment of APJs was almost certainly unconstitutional because the Director was clearly not a head of department).

293. See Lawson \& Seidman, supra note 287 , at $600-01$. 
would arise from a stronger remedy is probably unlikely to be worth the price of upset legal interests. Likewise, a strong remedy unencumbered by a de facto validity doctrine would likely have no deterrent effect if the structural defect arose only through the Supreme Court's announcement of a new principle or rule (such as a new, narrow reading of "head of department"). Other scenarios may exist in which the de facto validity doctrine properly limits remedies. But remedial values should be part of the remedial calculus, as the courts seek to balance chaos, third-party interests, and the overall effectiveness of the remedy with respect to the prevailing party, potential future parties, and the political branches.

\section{Northern Pipeline}

The Court's remedy in Northern Pipeline Construction Co. v. Marathon Pipe Line Co. generally satisfied key remedial valuesbetter than the remedy in Buckley, but not as well as the one in Ryder. In Northern Pipeline, the Court ordered the dismissal of a debtor's action in the bankruptcy court to recover money from a noncreditor third party. ${ }^{294}$ In response to the third party's challenge to the bankruptcy court's authority to hear the debtor's action, the Court prospectively invalidated the bankruptcy court's extensive statutory jurisdiction and stayed its judgment to provide Congress time to formulate a suitable solution. ${ }^{295}$

The remedy provided sufficient compensation, prospective enforcement, and incentives to litigate by giving the prevailing party what it requested and to what it would be entitled in other jurisdictional disputes. The prevailing party in Northern Pipeline had the debtor's action dismissed in such a manner that the debtor could re-file the action in a state or federal trial court. ${ }^{296}$ As a tactical matter, the non-debtor third party most likely sought to obtain a more favorable venue before a non-specialized (and, most likely, an Article III) judge, as compared to what non-debtors often perceive as debtor-friendly bankruptcy judges. ${ }^{297}$ By giving the prevailing party

294. See N. Pipeline Constr. Co. v. Marathon Pipe Line Co., 458 U.S. 50, $56-57$ (1982) (plurality opinion).

295. See id. at 56-57, 88-89.

296. See id. at 56-57.

297. Bankruptcy courts are, fairly or not, often perceived as debtor-friendly. See H.R. REP. No. 95-595, at 90-91 (1977); Debra L. Baker, Bankruptcy-The Last Environmental Loophole?, 34 S. TEX. L. REV. 379, 406 (1993); Martin Bienenstock, Marc Kieselstein \& David Fischer, Recharacterization \& Asset Securitization: "When Is a Duck a Duck," 1 DePAul Bus. \& COM. L.J. 575, 583 (2003); Kevin P. McDowell, Note, Statutory Authority 
exactly what it requested (i.e., dismissal of the current action and potentially a new hearing in another forum), the Court afforded similarly situated prevailing parties incentive to litigate by giving them the ability to litigate in a proper forum. This remedy would typically arise in analogous jurisdictional disputes and give the prevailing party that to which it was originally entitled had the bankruptcy court's jurisdiction not violated Article III.

The Court also achieved some level of deterrence with its remedy. ${ }^{298}$ The plurality, contrary to the wishes of two concurring justices, invalidated the statutory provision that granted the bankruptcy court broad jurisdiction over all "civil proceedings arising under title 11."299 Going forward, this remedy left bankruptcy proceedings up in the air because the bankruptcy courts lost their statutory jurisdiction over all claims, and the Court gave Congress a period of time (and an extension upon the Solicitor General's request) to create a constitutional bankruptcy system. ${ }^{300}$ During the Court's stay, the judiciary passed emergency bankruptcy rules, ${ }^{301}$ and Congress enacted new legislation more than two years later. ${ }^{302}$ Congress was required to create new law as to the bankruptcy system's structure, a process that was time-consuming and controversial. ${ }^{303}$ Such a far-reaching remedy serves to deter Congress from making other mistakes of the same ilk.

But the Court's accommodation for Congress may have also encouraged legislative lethargy. Congress in fact took more than two years to enact curative legislation. ${ }^{304}$ Despite the likely impossibility of proving a causal relationship between remedial limitations and congressional inaction, courts going forward should learn from the

for Bankruptcy Judges to Conduct Jury Trials: Fact of Fiction? In re United Missouri Bank of Kansas City, N.A., 56 Mo. L. REV. 729, 745 (1991).

298. See N. Pipeline Constr. Co., 458 U.S. at 89-90 (1982) (Rehnquist, J., concurring in the judgment).

299. See id. at 54 (plurality opinion) (quoting 28 U.S.C. § 1471(b) (1976 Supp. IV)).

300. See N. Pipeline Constr. Co. v. Marathon Pipe Line Co., 459 U.S. 813 (1982) (mem.).

301. See John E. Matthews, The Right to Jury Trial in Bankruptcy Courts: Constitutional Implications in the Wake of Grandfinanciera, S.A. v. Nordberg, 65 AM. BANKR. L.J. 43, 54 (1991).

302. See Stern v. Marshall, 131 S. Ct. 2594, 2603 (2012) (discussing the Bankruptcy Amendments and Federal Judgeship Act of 1984).

303. See, e.g., Lawrence P. King, The Unmaking of a Bankruptcy Court: Aftermath of Northern Pipeline v. Marathon, 40 WASH. \& LEE L. REV. 99, 107-20 (1983).

304. See Katelyn Knight, Note, Equitable Mootness in Bankruptcy Appeals, 49 SANTA ClARA L. REV. 253, 258 (2009) (noting that Congress took more than two years after Northern Pipeline to pass the Bankruptcy Amendments and Federal Judgeship Act of 1984). 
example and consider whether mitigating the effect of a structural defect may affect the political branches' response. The point is not that delay and emergency rules are always improper. Instead, the point is that congressional deterrence and lethargy should be additional factors in the courts' remedial analysis.

\section{RESPONDING TO STRUCTURAL REMEDIATION'S CHALLENGES}

The foregoing discussion reveals various structural remedies and their varied success in satisfying the three key remedial values. These decisions demonstrate that no one structural remedy is likely to be wholly satisfactory in all contexts, although certain remedies perform better than others. By considering these decisions and their structural remedies, courts and scholars are in a better position to identify the problematic structural remedies and contexts and then formulate appropriate responses.

So what are the potentially appropriate responses? Courts could proceed down three paths: (1) improving structural remedies and the discussion of remedial values, (2) limiting the nature of the safeguard and the rhetoric that surrounds it, or (3) reconsidering what interest, if any, regulated parties should have in structural challenges. ${ }^{305}$

\section{A. Improving Remedies}

Below I consider three possible ways to improve structural remedies. First, I suggest that the parties brief the issue of a proper remedy to bring the issue into focus. Second, courts could provide more significant equitable remedies, such as requiring Congress to cure the structural defect if the agency is to continue acting or invalidating the past actions of an improperly structured agency. These and similar remedies, as indicated from the analysis in Part III, are more likely to lead to the satisfaction of key remedial values. Finally, Congress should perhaps consider providing statutory remedies, such as scheduled damages.

\section{Briefing Remedial Options}

A relatively easy way to improve structural remediation would be to have the parties brief the issue of remedies. Briefing the issue, if

305. These paths need not be mutually exclusive. For instance, remedies may improve in certain scenarios but not in others, and judicial candor can help explain why the remedies must differ. Or, for another example, a party may brief the issues for the court, but the court may still be candid about not awarding requested relief. I shall, nonetheless, discuss each path separately for ease of discussion. 
nothing else, ensures that courts confront remedial options and values. Notably, structural remedies have failed most in these situations-such as in Free Enterprise Fund, Intercollegiate Broadcasting System, and Buckley-in which the prevailing party neither received the relief that it requested nor briefed remedies or remedial values in any detail. ${ }^{306}$ Indeed, Justice Rehnquist lamented in internal conference memos the lack of briefing as to the Court's de facto validity ruling in Buckley, which largely undermined remedial values and was later critiqued and limited by a unanimous Court in Ryder. ${ }^{307}$ Because courts often ignore the prevailing parties' perfunctory request for relief and provide remedies that fail to satisfy key remedial values, the parties have incentive to (and should) engage the courts in their arguments about the nature of an appropriate, meaningful structural remedy in light of the three key remedial values. By creating a conversation, as Ryder suggests, the remedies are more likely to match the Court's rhetoric about the underlying rights and fulfill remedial values.

This briefing may prove most useful after a court has established the nature of the structural defect. ${ }^{308}$ Parties may contest whether several structural defects exist in their briefing on the merits. For instance, in Free Enterprise Fund, the plaintiffs asserted challenges based on the Appointments Clause and the President's supervisory powers. ${ }^{309}$ The Supreme Court agreed with the plaintiffs only on their latter claim. ${ }^{310}$ The kind of violation could, of course, likely influence the appropriate remedy. Had the Court remanded the matter to the D.C. Circuit to address the remedial issue, the parties could have briefed the issue of remedies separately from the structural safeguard involved and considered germane remedial values (such as those discussed here and perhaps others, such as chaos, practicality of enforcement, and comity for the other branches).

306. See, e.g., Brief for Petitioners at 62, Free Enter. Fund v. Pub. Co. Accounting Oversight Bd., 130 S. Ct. 3138 (2010) (No. 08-861), 2009 WL 2247130; Reply Brief of Appellants, Buckley v. Valeo, 424 U.S. 1 (1975) (Nos. 75-436, 75-437), 1975 WL 171458, at *111 (providing some discussion on congressional intent and the propriety of severance and then stating that "the Commission itself should be invalidated"); Brief for Appellants at 17, Intercollegiate Broad. Sys., Inc. v. Copyright Royalty Bd., 684 F.3d 1332 (D.C. Cir. 2012) (Nos. 11-1083, 11-1103), 2011 WL 3918320.

307. See supra note 272; supra text accompanying note 284.

308. My thanks to Professor Bill Araiza for this insight.

309. Free Enter. Fund, 130 S. Ct. at 3147-48.

310. Id. at $3149,3151$. 


\section{Liberalized Equitable Remedies}

Beyond engaging with the remedial issue, courts could begin to provide more potent injunctive relief to render the underlying norms more meaningful. For instance, courts could require Congress to reconfigure a structurally sound agency, as the Court did in Northern Pipeline and Buckley. To strengthen the effect of requiring Congress to cure structural defects, courts could also limit their reliance on stays and de facto validity doctrines that seek to mitigate the effects of a more potent remedy. Doing so, as discussed above, provides increased incentives for those seeking redress because if Congress fails to reconfigure the structurally defective agency, regulated parties may not face future regulatory oversight. By placing regulatory programs into jeopardy and requiring Congress to confront its mistakes, the Court also provides a remedy that increases deterrence of wrongdoing. To be sure, the effect of remedies on Congress's motivation raises an empirical question which is probably impossible to answer. ${ }^{311}$ But requiring Congress to clean up its own mess might well lead the political branches to take structural safeguards more seriously. Likewise, providing wholly new proceedings before a properly fashioned agency as part of the injunctive relief-as in Ryder-would provide increased enforcement of the norm (through a specific-performance-like mechanism) and thus help achieve, at least in part, compensatory values and better achieve future enforcement for the prevailing party. The courts would be able to provide this more effective response to structural defects by using their familiar equitable powers that should generally present fewer concerns over judicial aggrandizement.

The awarding of more aggressive injunctive relief, however, comes with concerns. Aside from concerns about judicial overreaching, ${ }^{312}$ hobbling an agency may be too severe a sanction

311. In other contexts, Congress has responded to the Court's constitutional rulings and attempted to address the Court's concerns, suggesting that the Court's decisions do influence Congress in later legislation. For instance, after the Court invalidated childpornography prohibitions on First Amendment grounds, Congress passed new, more tailored legislation that adequately responded to the Court's concerns. See United States v. Williams, 553 U.S. 285, 289-91, 307 (2008) (describing how Congress sought to draft new child-pornography provisions in light of the Court's ruling in Ashcroft v. Free Speech Coalition, 535 U.S. 234 (2002), which struck down prior prohibitions on child pornography). Likewise, after the Court struck down Congress's attempt to regulate minors' ability to view pornography in Reno v. ACLU, 521 U.S. 844 (1997), Congress tried a second time to enact better-tailored prohibitions in the Child Online Protection Act ("COPA"). See Ashcroft v. ACLU, 542 U.S. 656, 661 (2004) (affirming the judgment that kept the preliminary injunction in place that prevented enforcement of COPA).

312. See BICKEL, supra note 187 , at 111-98. 
from the perspective of others whose conduct the agencies regulate. These other parties may well have ordered their businesses around the agencies' regulations and guidance. ${ }^{313}$ By providing an openended period during which the agency lacks power, other regulated parties would be uncertain whether to alter their businesses to become viable market participants unbounded by the regulatory state or to await curative legislation that will maintain the regulatory status quo. ${ }^{314}$

The sanction may also be an inappropriate judicial remedy because, as a matter of realpolitik, it favors those that seek to limit administrative action. Either house of Congress (or the President) could stop a controversial agency from functioning by withholding support for curative legislation. Such a remedy would permit that single house (or the President) to do what it (or he or she) could not otherwise do alone-abolish a particular agency. ${ }^{315}$ This possibility is not merely theoretical. Consider the recent structural challenge to the CFPB, established by the Dodd-Frank Act in $2010 .{ }^{316}$ If the remedy for the alleged structural violations was to invalidate all of the CFPB's actions until the passage of curative legislation, the CFPB may well never rise again because Republicans, who have long been hostile to its existence and were the minority party when it was created, now control the House. ${ }^{317}$

\section{Legislative Participation}

Because of the drawbacks associated with judicially crafted equitable relief, one possible response to this problem is for Congress to step in and provide complementary remedies by statute, largely

freeing courts from having to worry about proper judicial

313. The Supreme Court, however, did not appear too troubled by settled legal interests in New Process Steel, L.P. v. NRLB, 130 S. Ct. 2635 (2010), when it held that the NLRB lacked authority to issue more than 600 of its orders because it violated a statutory quorum requirement. See id. at 2639, 2644-45.

314. See Gewirtz, supra note 34, at 604 (considering third parties' interests when fashioning remedies).

315. See Gorod, supra note 16, at 924.

316. See First Amended Complaint for Declaratory and Injunctive Relief IIII 240-45, State Nat'l Bank of Big Spring v. Geithner, No. 1:12-cv-01032 (D.D.C. Sept. 20, 2012), 2012 WL 4229466 (asserting several structural challenges to the CFPB).

317. See, e.g., Pat Garofalo, House Republicans Propose Cutting Consumer Protection Bureau and Foreclosure Prevention, THINK PROGRESS, (Apr. 13, 2012, 5:40 PM), http:// thinkprogress.org/economy/2012/04/13/464400/financial-services-budget-repeal

/?mobile=nc; Suzy Khimm, The GOP's New Push to Defang the CFPB, WASH. POST WONKBLOG, (Feb. 8, 2012, 4:33 PM), http://www.washingtonpost.com/blogs/wonkblog /post/the-gops-new-push-to-defang-the-cfpb/2012/02/08/gIQA1DrfzQ_blog.html. 
remediation. A statutory remedy could provide new incentives for litigants to seek redress by, for instance, providing scheduled, monetary damages. Because a structural harm is hard to quantify, scheduled damages (like liquidated damages) may serve a useful role. ${ }^{318}$ Scheduled damages permit the legislature to assign an amount that, in the legislature's view, serves to compensate for past harms and to deter. ${ }^{319}$ The scheduled damages would thereby provide more incentive for regulated parties to seek redress. Along with injunctive relief to prevent future violations, such a monetary award would thus provide the regulated party with a remedy that promotes the three underlying remedial virtues. ${ }^{320}$ This approach would promote the "passive virtues" of a limited judiciary by permitting the legislature to develop more carefully crafted remedies. ${ }^{321}$

As part of compensating prevailing parties with scheduled damages, Congress could also provide attorneys' fees for a prevailing party under a similar rubric as found under 42 U.S.C. $§ 1988 .{ }^{322}$ Doing so would allow prevailing parties to obtain most of their litigation costs and place them on more equal footing with other kinds of constitutional litigation, such as those brought under the Civil Right Acts under Title 42 of the U.S. Code. ${ }^{323}$ Providing attorneys' fees alone would not, however, likely provide sufficient incentive for regulated parties to bring structural challenges. Such recovery would place the party only in the same, not a better, position as it was before the challenge. A significant monetary award on top of the cost of bringing an action would be necessary to provide sufficient incentive, especially in light of possible perceived damage to the relationship between the regulated party and the official or agency.

That said, even if substantial scheduled awards and attorneys' fees provide compensation and incentive to litigants, they still may not prevent Congress from transgressing constitutional limits. Such

318. See Bray, supra note 104, at 755-57 (noting that scheduled damages, a form of "announc[ed]" remedies, may not be optimal, but they are "well suited to the world of the second best").

319. See id. at 761-63 (arguing that scheduled damages can be more beneficial from a compensatory and distributive justice theory for difficult-to-quantify harms).

320. See supra Part II.B.2.

321. See BICKEL, supra note 187, 111-98.

322. 42 U.S.C. $\S 1988$ (2006).

323. See id. (permitting reasonable attorneys' fees for "any action or proceeding to enforce a provision of sections 1981, 1981a, 1982, 1983, 1985, and 1986 of this title, title IX of Public Law 92-318 [20 U.S.C. § 1681 et seq.], the Religious Freedom Restoration Act of 1993 [42 U.S.C. $\$ 2000$ bb et seq.], the Religious Land Use and Institutionalized Persons Act of 2000 [42 U.S.C. $\S 2000 c c$ et seq.], title VI of the Civil Rights Act of 1964 [42 U.S.C. $\S 2000$ d et seq.], or section 13981 of this title" (alterations in original)). 
awards, whether paid from an agency's budget or the U.S. Treasury, would not likely deter Congress. Neither legislative house nor its members would be meaningfully affected by damages even in the high six- or seven-figures range. Scheduled damages, therefore, may fail to achieve one of their three key purposes. But considering the unknown or limited deterrent effect of remedies on Congress, ${ }^{324}$ this remedial failure in the structural context may be of limited importance, given such a remedy's other virtues.

Perhaps more significantly, Congress is unlikely to create a monetary remedy that is meant to incentivize challenges to congressional authority. Not only has Congress been leery of extending damage awards and causes of action that implicate the federal purse, ${ }^{325}$ but it would almost certainly be hesitant to help regulated parties bring suits that are meant to hamstring legislative discretion. Instead, Congress has addressed remedial concerns only by establishing some "fallback" provisions that dictate results when the Court invalidates a statutory provision. ${ }^{326}$ Thus, statutory damages, which may provide a generally successful remedy, stand little chance of enactment.

\section{B. Judicial Candor Concerning Safeguards' Limitations}

The potential implausibility of scheduled damages and more meaningful equitable relief may be strong evidence that structural remedies cannot be rendered more consequential for regulated parties. Courts could concede that, despite judicial declarations of the importance of structural design, ${ }^{327}$ many safeguards are not meaningful for regulated parties because other considerations-such as regulatory chaos, sovereign immunity, and judicial minimalist remedies-are deemed more important than the key remedial values of compensation, litigation incentive, and deterrence. The preeminence of other values suggests that the safeguards serve primarily as aspirational guidelines for the political branches to follow when constructing administrative entities. If a branch of government seeks to vindicate those safeguards, the courts' current remedies, which largely look to severance to avoid disturbance to the regulatory scheme, may well be sufficient to render structural norms meaningful

324. See Mark Seidenfeld, Pyrrhic Political Penalties: Why the Public Would Lose Under the "Penalty Default Canon," 72 GEO. WASH. L. REV. 724, 733 (2004) (suggesting that a "Penalty Default Canon" would likely lead to Congressional inaction).

325. See CHEMERINSKY, supra 134, at 614

326. See Bowsher v. Synar, 478 U.S. 714, 735-36 (1986).

327. See supra Part I. 
to that branch of government. But, for pragmatic or historic reasons, judicial structural remedies often fail to validate individual interests. Despite the Court's protestations, the safeguards may therefore be more akin to technicalities and protocol for regulated parties. ${ }^{328}$

Limiting structural safeguards because of concerns over regulatory chaos would be consistent with Professor Levinson's theory that aggressive remedies may lead to diminished rights. ${ }^{329}$ As Levinson noted when discussing constitutional remedies generally, as significant remedies increase the "price" of a violation, courts will find fewer violations. ${ }^{330}$ As fewer violations arise, the breadth and importance of the safeguard will decrease as the courts find various bases for finding no underlying right.

Indeed, the Court has candidly limited structural challenges to administrative adjudication based on Article III, relying on various pragmatic factors to avoid ever finding a violation. ${ }^{331}$ It has thereby avoided having to decide the nature and scope of a suitable remedy. But, as a consequence, the Court has crafted a relatively impotent structural safeguard. For instance, in CFTC v. Schor, ${ }^{332}$ the Court found no structural violation after taking a functional approach that balanced several factors-including Congress's reason for granting a non-Article III tribunal jurisdiction to hear certain claims and the significance of the incursion into the Article III courts' authority. ${ }^{333}$ To be sure, the Court may be criticized for not going one step further by acknowledging that individuals may find little value in Article III protections within the administrative context. But its decisions clearly reveal that because of functional or other prudential limitations, the safeguard may provide little or no litigation benefits to a party regulated by administrative agencies. ${ }^{334}$ And the regulated parties' voluntary waiver of their Article III rights in that case (by agreeing to dismiss the claims in federal court and resolve the claims before the

328. See Ryder v. United States, 515 U.S. 177, 182 (1995) (quoting Buckley v. Valeo, 424 U.S. 1, 125 (1976) (per curiam)) (stating that the Appointments Clause is not merely etiquette or protocol).

329. See Levinson, supra note 32, at 889.

330. See id. (considering the Eighth and Fourteenth Amendments).

331. See, e.g., CFTC v. Schor, 478 U.S. 833, 851 (1986); Thomas v. Union Carbide Agric. Prods. Co., 473 U.S. 568, 571-75 (1985); Crowell v. Benson, 285 U.S. 22, 44-46, 5051 (1932). These factors include (1) whether deciding the claims implicates essential attributes of judicial power, (2) which powers are normally exercised by Article III courts, (3) the origin and importance of the right involved, (4) the congressional concerns that led to innovative structures, and (5) consent. See Schor, 478 U.S. at 851.

332. 478 U.S. 833 (1986).

333. See id. at 848-51.

334. See, e.g., id. 
agency) reveals that the parties' understood the structural safeguard was of minimal importance to their other goals. ${ }^{335}$ In fact, the Court moved towards removing any lingering doubt over the limited reach of Article III into administrative adjudication in Stern, when it repeatedly distinguished agency adjudication as different in kind from the unconstitutional bankruptcy adjudication at issue (albeit without explaining why). ${ }^{336}$

Judicial candor concerning structural safeguards' and remedies' limitations - such as in the Article III context of administrative adjudications-is preferable to the underlying doctrine's intentional or subconscious obfuscation. As Professor Paul Gewirtz has cogently argued about constitutional remedies generally, the moral basis for judicial power and accountability is founded upon candor. ${ }^{337}$ A lack of candor might, at times, help avoid dignitary harms or public resistance. ${ }^{338}$ Yet the regulated parties would likely prefer to have an honest accounting of the norm and its remedial limitations instead of judicial blandishments, if for no other reason than to have better information when deciding whether to invest resources in future structural challenges. ${ }^{339}$ Furthermore, even if judicial deception might be necessary to preserve the judiciary's authority when the political branches resist the courts' judgments, ${ }^{340}$ the political branches have not done so concerning structural defects.

When the Court is not forthright about the limitations concerning, or absence of, a meaningful remedy, it undermines its attempt to signal the safeguard's importance. A first principle of remedial theory is that "the remedy should be selected and measured to match [the substantive] policy." 341 When courts speak in powerful terms of a safeguard but then provide only a limited remedy without explaining the reasons for the limitation, they are narrowing the safeguard without registering any form of protest or otherwise explaining the necessity of doing so. ${ }^{342}$ Not only does the relatively

335. See id.

336. Stern v. Marshall, 131 S. Ct. 2594, 2614-15 (2011).

337. See Gewirtz, supra note 34, at 667.

338. See id. at 668-84.

339. Cf. ImMANUEl KANT, CRITIQUe OF PRACTICAL REASON 347 (Lewis White Beck ed. \& trans., The Univ. of Chi. Press 1949).

340. See Gewirtz, supra note 34, at 668-84.

341. DoBBS, supra note 117, at 3 .

342. Limiting remedies is not only within the province of the judiciary. "Political actors are well aware that one can limit substantive rights by limiting remedies. Substantially all tort reform proposals actually enacted have been limitations on remedies ...." Douglas Laycock, How Remedies Became a Field: A History, 27 REV. LiTIG. 161, 165 (2008). 
inconsequential remedy suggest judicial antipathy toward the right, but the lack of candor undermines the judiciary's authority that derives from explaining its decisions. ${ }^{343}$ In other words, when courts employ inadequate remedies for unexplained reasons, they weaken both the safeguard and themselves. ${ }^{344}$ Candid judicial recognition of its under-effective remedies is preferable to an obfuscated doctrine for courts, for scholars, and-perhaps most importantly-for regulated parties interested in making well-informed litigation choices.

\section{Limiting Challenges from Regulated Parties}

Judicial candor about structural remedies' current and future limitations might also lead to a reassessment of a closely related issue-regulated parties' relationship with structural safeguards. Although the courts have referred to certain safeguards as "personal rights" and implied private rights of action in the Constitution for structural challenges, the lack of effective remedies for certain safeguards suggests that there is no meaningful personal right at all. ${ }^{345}$ Instead, regulated parties have only some kind of ill-defined interest or opportunity to register objections that often cannot be fully vindicated.

The fact that familiar remedial values often do not rest as comfortably in a structural context supports this view. Compensating for past injury is difficult because of immunity and valuation issues. Even the most successful specific-performance-like remedy only compensates in part because it does not provide compensation for litigation and other expenses incurred because of the structural defect. Without monetary remedies, providing a regulated party an incentive to litigate is difficult because the regulated party is uncertain whether any benefit will come from the structural

\footnotetext{
343. See Gewirtz, supra note 34, at 667.

344. See Levinson, supra note 32 , at $887-88$ (referring to the concept of abridging a right through limited remedies as "remedial substantiation"). When courts provide a limited structural remedy without explaining why, they are implicitly applying a very familiar remedial concept that is most visible in the context of breach-of-contract remedies-waste. See, e.g., Peevyhouse v. Garland Coal Mining Co., 382 P.2d 109, 112-13 (Okla. 1962) (relying on "economic waste" to provide minimal recovery to plaintiffs); RESTATEMENT (SECOND) OF CONTRACTS § 348(2)(b) \& cmt. c (1981). The Court clearly signals through its remedy that the breach-here of a constitutional safeguard-is a minor transgression, not worthy of full remediation. The concept of waste may have merit in contract law, but the concept is troubling for constitutional safeguards that are intended, as the Court has said, to be prophylactic and, as constitutional provisions, important by definition.
}

345. See Marbury v. Madison, 5 U.S. (1 Cranch) 137, 163 (1803). 
challenge. Indeed, even a victorious challenge may provide the prevailing litigant with no substantive advantage. And deterrence may be an inappropriate value in the structural-defect context because the Court's doctrine is ever shifting, rendering Congress less blameworthy in failing to adhere to structural limits, and because Congress may not respond to deterrence-based remedies anyway. ${ }^{346}$ Moreover, a determination of whether these values are satisfied will often be subjective and highly indeterminate. These difficulties may reveal judicial inattention to structural remedies. Or they could suggest that the courts' understanding of the current relationship between legal safeguards and the regulated parties is unsound. ${ }^{347}$

Perhaps, instead, only the branches of government themselves should have the ability to enforce those structural safeguards for which regulated parties can secure no meaningful remedies. The structural safeguards, after all, protect the three branches from one another. ${ }^{348}$ And the branches often seek, with or without regulated parties, to vindicate the safeguards in litigation. ${ }^{349}$ Limited structural remedies for the branches may also be appropriate because the Court can respect the norm largely without considering key remedial values that matter to a "wronged" party. For instance, the President usually loses power when legislation violates the norms of presidential supervision under Article II or disregards the Appointments Clause. But he or she (or his or her predecessor)_outside of the rare context

346. See Seidenfeld, supra note 324, at 733.

347. See Donald H. Zeigler, Rights Require Remedies: A New Approach to the Enforcement of Rights in the Federal Courts, 38 HASTINGS L.J. 665, 678 n.73 (1987) (referring to WESLEY NEWCOMB HOHFELD, FundAMENTAL LEGAL CONCEPTIONS AS APPLIED IN JUDICIAL REASONING 38 (Walter Wheeler Cook ed. 1919)).

348. See supra Part I.

349. See, e.g., Bowsher v. Synar, 478 U.S. 714, 719 (1986); INS v. Chadha, 462 U.S. 919, 940 (1983); Buckley v. Valeo, 424 U.S. 1, 7-8 (1976) (per curiam); Humphrey's Ex'r v. United States, 295 U.S. 602, 626-30 (1935); Myers v. United States, 272 U.S. 52, 107-08 (1926). There is, however, significant current debate as to whether Congress, or one of its houses, has the right to file suit or appear in court. See United States v. Windsor, $133 \mathrm{~S}$. Ct. 2675, 2686-89 (2013) (referring favorably to the House's participation in the lawsuit when the Executive Branch refused to defend the federal law at issue, but noting the problematic nature of the House's involvement as a routine matter). Compare Tara Leigh Grove \& Neal Devins, Congress's (Limited) Power to Represent Itself in Court, 99 CORNELL L. REV. (forthcoming 2014), available at http://papers.ssrn.com /sol3/papers.cfm?abstract_id=2313950 ("We argue that Congress has the constitutional power to investigate the executive and judicially enforce subpoenas but that it cannot defend federal statutes in court. We thereby challenge a widespread assumption among jurists and scholars that, when the executive branch declines to defend a federal law, Congress may take over the litigation."), with Frost, supra note 192, at 952 ("Congress ... has an interest in participating in litigation to protect its institutional prerogatives, as it has recognized in a handful of cases."). 
of Congress overriding a President's veto-participated in creating the problem by signing the legislation in the first instance. ${ }^{350} \mathrm{~A}$ minimalist remedy that removes the structural defect and otherwise leaves the parties where they were may well be the most appropriate remedy to account for the "prevailing" branch's part in creating its own injury.

Regulated parties may be left with, at best, some kind of interest that they have standing to assert, but for which they are not entitled to any meaningful remedy. This interest-somewhere between a right and nothing at all - may be all that a regulated party can hope to have in structural safeguards. If structural remedies remain inadequate, scholars, courts, and litigants should begin to consider how remedies for regulated parties directly affect their interest in these safeguards and how to respond appropriately.

\section{CONCLUSION}

At their core, the remedial inadequacies for structural challenges reveal that the Supreme Court is approaching a crossroads. It has appeared receptive to regulated parties' structural challenges in the past two decades, rarely failing to exalt the U.S. Constitution's structural safeguards and encouraging regulated parties to assert structural claims. But the remedies that courts have forged, by ignoring remedial values relevant to regulated parties, have often failed to match judicial paeans to the centrality of structural norms. As structural litigation and inadequate structural remedies continue to proliferate, the limited nature of structural remediation will become only more apparent. By considering remedial values more carefully now, all relevant players-courts, scholars, and regulated parties - can decide how best to move forward. 